\title{
Progress in micro RNA focused research in endocrinology
}

\author{
Voglova K, Bezakova J, Herichova I \\ Department of Animal Physiology and Ethology, Faculty of Natural Sciences, \\ Comenius University Bratislava, Slovak Republic \\ E-mail: herichova@fns.uniba.sk
}

\begin{abstract}
Micro RNAs (miRNAs) are small regulatory molecules of increasing biologists' interest. miRNAs, unlikely mRNA, do not encode proteins. It is a class of small double stranded RNA molecules that via their seed sequence interact with mRNA and inhibit its expression. It has been estimated that $30 \%$ of human gene expression is regulated by miRNAs. One miRNA usually targets several mRNAs and one mRNA can be regulated by several miRNAs. miRNA biogenesis is realized by key enzymes, Drosha and Dicer. miRNA/mRNA interaction depends on binding to RNA-induced silencing complex. Today, complete commercially available methodical proposals for miRNA investigation are available. There are techniques allowing the identification of new miRNAs and new miRNA targets, validation of predicted targets, measurement of miRNAs and their precursor levels, and validation of physiological role of miRNAs under in vitro and in vivo conditions. miRNAs have been shown to influence gene expression in several endocrine glands, including pancreas, ovary, testes, hypothalamus, and pituitary.
\end{abstract}

Key words: RISC, Argonaute, hormone, adrenal, pancreas, pituitary, angiotensin

\section{Why is everyone incredibly crazy about miRNA?}

Based on the recent knowledge, regarding the miRNAs structure and their interactions with mRNA, it has been estimated that $30 \%$ of human genes are modulated/regulated by miRNAs (Lewis et al. 2005).

Scientific interest in miRNA exponentially grew since the beginning of the second millennium. Recent scientometric search have revealed that there are nearly 5000 papers about miRNAs published in 2014, most of them (1426) have been published in PloS One. The research was mostly conducted in the U.S.A., followed by China and Germany. The research topics are mostly focused on the biochemistry or medicine (search performed in January 15, 2016 by Scopus, key word: miRNA). The cross search "miRNA and hormone" issued 2000 papers.
Database miRBase at the beginning of the year 2016 registered 1881 precursors and 2588 mature miRNAs in Homo sapiens. According to the miRTarBase database (http://mirtarbase.mbc.nctu.edu. $\mathrm{tw} / \mathrm{php} /$ search.php?opt=species\&org=hsa), there are 65535 evidences for interaction of miRNAs with mRNA. The number of interactions is much higher in comparison with the number of miRNAs since miRNAs usually interact with several target genes. There is a strong experimental evidence for miRNA-target interaction in 5858 cases. In these cases, the evidence was provided by combination of immunoprecipitation, luciferase reporter assay, real time PCR, and Western blot.

The most frequently reported miRNA is hsa-miR155-5p with 228 reported interactions. Many interactions have independently been reported several times;

Corresponding author: Iveta Herichova, PhD., Department of Animal Physiology and Ethology, Faculty of Natural Sciences, Comenius University in Bratislava, Ilkovicova 6, 84215 Bratislava, Slovak Republic; phone: 00421-2-60296572; 
e.g., interaction of hsa-miR-155-5p with CCAAT/enhancer binding protein beta has been reported eight times. Exclusion of all parallel proofs has revealed 154 interactions of hsa-miR-155-5p with certain genes (CCND1, MYC, MYB, ETS1, WEE1, RUNX2, TP53INP1, FOXO3, SOCS1, SMAD1 etc.).

The second most extensively studied miRNA is hsa-miR-21-5p with 213 interactions. There have independently been reported 40 interactions of hsamiR-21-5p with phosphatase and tensin homolog (PTEN) and 36 interactions with programmed cell death 4 (PDCD4). Exclusion of all parallel proofs have revealed interactions of hsa-miR-21-5p with 86 genes (PTEN, BCL2, VEGFA, PDCD4, EGFR, E2F1, SP1, TGFBR2, RECK, ERBB2 etc.).

The most frequently reported gene is PTEN with 125 reported interactions with some miRNAs. Interaction of PTEN with hsa-miR-21-5p is the most frequently reported one. There have occurred 41 interactions of PTEN with miRNAs after exclusion of repetitions (hsa-miR-21-5p, hsa-miR-29b-3p, hsamiR-221-3p, hsa-miR-17-5p, hsa-miR-29a-3p, hsamiR-200a-3p, hsa-miR-26a-5p, hsa-miR-222-3p, hsamiR-20a-5p, hsa-miR-141-3p etc.). The second most frequently reported gene is B-cell CLL/lymphoma 2 (BCL2) with 95 interactions, regulated by 41 miRNAs (after exclusion of parallel proofs).

Recent overview has revealed that the processes, involved in cell cycle regulation and deregulation, are most often studied in relation to miRNA. Although, there exists an extensive in silico research and free online tools for performing it, no sufficient attention has been given to growing miRNAs field in other areas that require more complex (whole organ or organismal) evidence to prove their impact on a physiological function. This can be caused by the fact that miRNAs may target from several to many mRNAs. Moreover, after-interactions can influence the response to miRNAs administration in complex multicellular organisms.

The aim of this review is to show ways how to study and validate the miRNA functions and to provide a survey of existing knowledge about known roles of miRNAs in endocrinology.

\section{What are miRNAs and where are they coming from?}

miRNAs are small (17-25 nucleotides), noncoding, single stranded (ssRNA) types of RNA that belong to a large collection of small non-coding regulatory RNAs. They have been found in various organisms, including plants, unicellular eukaryotes, and mammals, including humans. miRNAs possess a capacity to post-transcriptionally affect the biological activity of mRNA.

Besides miRNAs, there are several other groups of non-coding RNAs (ncRNAs) (Table 1). The number of RNAs within existing classes is still increasing and newly discovered classes of RNAs are still emerging. Small interfering RNA (siRNA) is involved in the regulation of $m R N A s$ and is capable of cleavage of RNAs, derived from viruses and retroelements. Unlikely miRNAs, siRNAs have high sequence complementarity to their target mRNAs (Filipowicz 2005). Other type of non-coding RNA is a small nuclear RNA (snRNA) that is involved in a splicing of small nucleolar RNA (snoRNA), performing ribosomal rRNA modification and its processing in the nucleolus (Matera et al. 2007). Table 1 provides a short overview of ncRNAs identified in mammals (miRNAs identified in other classes not present in humans are not listed) with explanation of their names and brief description of their functions (Holley and Topkara 2011; Dogini et al. 2014).

The firstly discovered miRNA was lin-4 found in the Caenorhabditis elegans (C. elegans) in 1993 by the team of Victor Ambros during the study of larval development (Lee et al. 1993). miRNA let-7 was later discovered by another research group also in the $C$. elegans studies. It has been reported that both $\mathrm{miR}$ NAs participate in the negative regulation of translation (Reinhart et al. 2000). An intensive research centered to miRNAs has begun with the paper of Fire et al. (1998) reporting about powerful effect of doublestranded RNA on the gene expression.

\section{Nomenclature of miRNAs}

Nomenclature of miRNAs obeys strict rules that significantly contribute to the progress in this field. Each miRNA has assigned sequential numerical identifier and usually use three or four letter prefixes to designate the species (e.g. hsa - Homo sapiens, mmu - Mus musculus, dme - Drosophila melanogaster). Mature miRNA sequences are designated with "miR", while precursor forms have assigned "mir". Paralogue mature sequences, with differences only in one-two positions, are given lettered suffixes (e.g. mmu-miR-10a and mmu-miR-10b in mouse) or number suffixes in case of differences in precursor forms that give rise to identical mature miRNAs (dmemir-281-1 and dme-mir-281-2 in D. melanogaster). Two mature strands that originate in the opposite arms of one precursor are named after $3^{\prime}$ and 5 'end of precursor miRNA sequence e.g. miR-21-5p ( $5^{\prime}$ end) 
Table 1

non-coding RNA classification

\begin{tabular}{|c|c|c|c|c|}
\hline & Abbreviation & Full name & Mean size & Function \\
\hline \multirow[t]{3}{*}{ long ncRNA } & rRNA & Ribosomal RNA & $\sim 1.9 \mathrm{~kb}$ & Essential for protein synthesis \\
\hline & XIST RNA & $\mathrm{X}$-inactive specific transcript & $\sim 17 \mathrm{~kb}$ & Chromosome $\mathrm{X}$ inactivation \\
\hline & other lncRNA & & $>200 \mathrm{nt}$ & $\begin{array}{l}\text { Involved in epigenetic modification and post- } \\
\text { transcriptional processing }\end{array}$ \\
\hline \multirow[t]{9}{*}{ small ncRNA } & miRNA & mature microRNA & $18-21 \mathrm{nt}$ & RNA silencing \\
\hline & siRNA & small interfering RNA & $21 \mathrm{nt}$ & $\begin{array}{l}\text { RNA silencing, defense against viruses and } \\
\text { transposon activity }\end{array}$ \\
\hline & piRNA & Piwi interacting RNA & $26-30 \mathrm{nt}$ & $\begin{array}{l}\text { Regulation of transposon activity and } \\
\text { chromatin state }\end{array}$ \\
\hline & tRNA & transfer RNA & $70-90 \mathrm{nt}$ & translation \\
\hline & snRNA & small nuclear RNA & $100-300 \mathrm{nt}$ & RNA splicing \\
\hline & snoRNA & small nucleolar RNA & $60-300 \mathrm{nt}$ & RNA modification \\
\hline & scaRNA & small Cajal body RNA & $200 \mathrm{nt}$ & RNA modification \\
\hline & gRNA & guide RNA & $40-80 \mathrm{nt}$ & RNA editing \\
\hline & rasiRNA & $\begin{array}{l}\text { repeat associated small } \\
\text { interfering RNA }\end{array}$ & $24-27 \mathrm{nt}$ & $\begin{array}{l}\text { Orientation of heterochromatin in the } \\
\text { formation of centromeres }\end{array}$ \\
\hline \multirow{5}{*}{$\begin{array}{l}\text { other frequent } \\
\text { abbreviations }\end{array}$} & pri-miRNA & primary precursor miRNA & $\sim 100 \mathrm{nt}$ & \\
\hline & pre-miRNA & precursor miRNA & $\sim 70 \mathrm{nt}$ & \\
\hline & ssRNA & single stranded RNA & & \\
\hline & dsRNA & double stranded RNA & & \\
\hline & ncRNA & non-coding RNA & & \\
\hline
\end{tabular}

and miR-21-3p ( 3 'end). In some cases, asterisk can indicate the passenger strand of mature miRNA. The numbering of miRNA genes is sequential and usually reflects chronology of miRNA identification. let7 and lin- 4 are rare exceptions, accepted because of historical reasons (Griffiths-Jones et al. 2006).

\section{miRNA transcription}

Biogenesis of miRNAs (Figure 1) starts with their transcription, which is an important step in the regulation of their expression. Some of the miRNA genes are transcribed from their own promoters from regions between transcription units (intergenic miRNA). Approximately $50 \%$ of miRNAs are located in the intronic part of known protein coding genes (intronic miRNA) (Rodriguez et al. 2004; Kim 2005).
Subsequent analysis of miRNA biogenesis has shown that approximately $50 \%$ of miRNAs are clustered in polycistronic regions that involve usually two or three genes per cluster in human (Lee et al. 2002; He et al. 2005).

Although, the majority of small non-coding RNAs, such as tRNA or snRNA, are transcribed by polymerase III, there is evidence indicating that majority of the mature miRNAs are originally polymerase II products. The primary transcript (pri-miRNA) is much longer (over $1 \mathrm{~kb}$ ) than conserved stem loops sequence of pre-miRNA and contains a 5'-7-methyl guanosine cap and poly(A) tail (Lee et al. 2002). These structures are typical for transcripts that are produced by the RNA polymerase II. Lee et al. (2004a) have provided the first experimental evidence that a single polycistronic miRNA gene, containing miR- 
23a, miR-27a, and miR-24-2, is transcribed by polymerase II. Polymerase III, however, may also participate on miRNA biogenesis, particularly in case of intronic miRNAs transcription. miRNAs generated from introns of protein coding genes were previously believed to use only their host transcript carriers, involving polymerase II. However, further analysis has revealed that $35 \%$ of the currently known intronic miRNAs have upstream regulatory elements, whereas $30 \%$ of intronic RNAs are associated with polymerase II and other 5\% contains polymerase III regulatory elements (Monteys et al. 2010). Thus, both polymerases participate on transcription of miRNA through specific promoters or regions that are highly similar to the regions of protein-coding genes such as CpG island, TATA box, and TFIIB recognition region (Ozsolak et al. 2008; Corcoran et al. 2009).

\section{miRNA processing by microprocessor complex and Dicer}

The maturation of miRNAs continues in the nucleus by cleaving pri-miRNA into approximately 70nt hairpin structure, called precursor miRNA (premiRNA). Microprocessor complex, which consists of RNase III enzyme (Drosha) and DiGeorge syndrome critical region gene 8 (DGCR8), known as Pasha in D. melanogaster and C. elegans and double-stranded RNA-binding domain (dsRBD) protein, takes action in this process (Lee et al. 2003; Denli et al. 2004; Landthaler et al. 2004). Drosha cleaves RNA by binding to the hairpin producing 2 nt overhang typical for $3^{\prime}$ end of pre-miRNA. Both, Drosha and DGCR8, have to be active during the processing of pri-miRNA. Typical pri-miRNA consists of hairpin structure and stem that is about 33 nt long. A region important for processing by Drosha is a stem and two flanking ssRNAs. These segments are recognized by DGCR8 that navigates Drosha to cut stem several nts away from the stem junction at the base of the hairpin, which results in producing pre-miRNA (Han et al. 2006).

In 2007, several experimental teams discovered a type of miRNA that is able to skip Drosha cleavage, called Mirtrons. These intron-mediated miRNAs are produced by splicing from their host transcript. They form hairpin structures, resembling the classic premiRNA just by splicing machinery. It enables further processing in the cytoplasm by Dicer bypassing the Drosha activity. Mirtrons are present in various species, including mammals (Berezikov et al. 2007; Okamura et al. 2007).

After processing by microprocessor complex in the nucleus, pre-miRNA is transported into the cy-

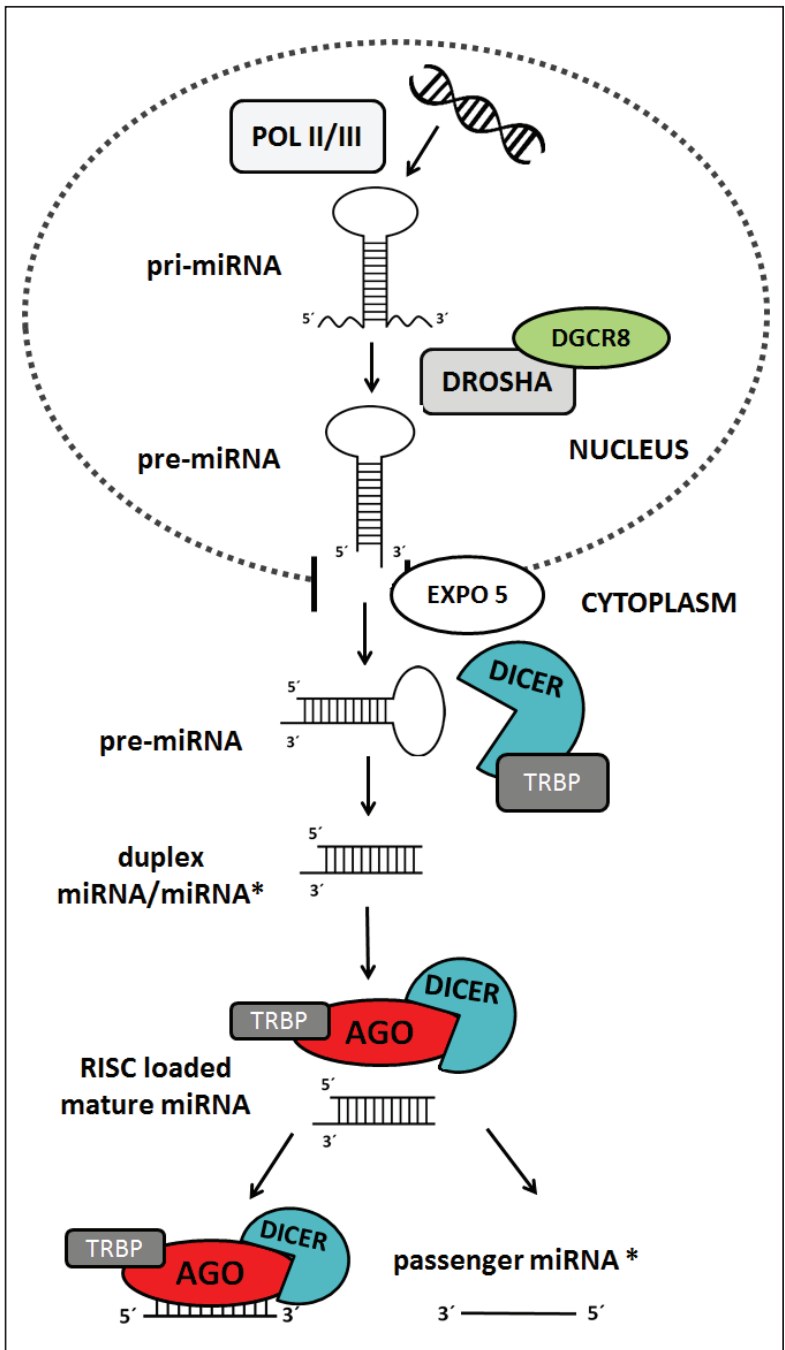

Figure 1. miRNA biogenesis pathway. After transcription by polymerase II/III, a primary transcript (pri-miRNA) is processed in the nucleus by RNase III (Drosha) and DiGeorge critical region gene 8 (DGCR8) into precursor miRNA (premiRNA). Transporting pre-miRNA from the nucleus is mediated by Exportin 5 (Expo5). In the cytoplasm, pre-miRNA is cleaved by RNase III called Dicer together with its catalytic partner TAR-binding protein (TRBP) and forms mature miRNA duplex. miRNA duplex is subsequently incorporated to the RISC (RNA-induced silencing complex) that consists of one member of Argonaute family proteins (AGO), TRBP and Dicer. After strand selection, leading (or guide) strand of miRNA duplex exerts translation repression or cleavage of mRNA.

toplasm by binding to the Exportin 5 (Yi et al. 2003). Exportin 5 is a member of karyopherin family of nucleocytoplasmic transport factors, firstly identified to mediate the nuclear export of adenovirus VA1. However, it can also function as a secondary receptor for tRNA nuclear export. The action of this transporter is 
based on the presence of GTP-bound form of the Ran GTPase in the nucleus. Cytosolic factor-facilitated hydrolysis of Ran-GTP to Ran-GDP induces release of cargo, in this case pre-miRNA, into the cytoplasm (Calado et al. 2002; Yi et al. 2003).

Once the pre-miRNA is transported into the cytoplasm, it is cleaved by the second RNase III called Dicer (Bernstein et al. 2001). This enzyme is essential for processing pre-miRNA into bioactive moleculemature miRNA. In vertebrates and C. elegans, there is present only one type of Dicer, while $D$. melanogaster genome contains two forms of this RNase III enzyme, from which Dicer-1 is involved in miRNA biogenesis, while Dicer-2 participates in another form of RNA interference (Lee et al. 2004b). Dicer homologues are typical by several domains - two catalytic RNase III domains, PAZ domain, dsRNA binding domain, and ATPase/RNA helicase domain (Kim 2005; Filipowicz 2005). Dicer is capable of cleavage activity itself, without any cofactors. Anyway, association of this enzyme and protein from Argonaute family has probably additional functions in providing miRNA stability and effector complex formation and action (Kim 2005). Argonaute proteins are important players in the gene silencing. They are involved not only in miRNA or siRNA functions, but the subfamily of Piwi Ago proteins also affect piRNA mediating translation repression (Hock and Meister 2008).

Interaction between Dicer and pre-miRNA is provided by helicase domain. Protein TRBP (trans-activation response RNA-binding protein) that contains double stranded RNA binding domain has an important role in the enhancing and modulating of Dicer activities (Chendrimada et al. 2005).

The Dicer product is a double stranded miRNA helix with approximately $2 \mathrm{nt} 3$ 'overhang at both ends. Dicer has a molecular ruler and is able to cut dsRNA in a specific distance from the beginning of the helix (MacRae et al. 2006).

\section{RISC assembly and strand selection}

After cleaving by Dicer, it is necessary to unwind the double stranded helix of miRNA/miRNA ${ }^{*}$ and separate the guide strand with biological function from the passenger strand. This process is called strand selection and it determines which strand will form active complex with RISC (RNA-induced silencing complex) and which one will be degraded (Schwarz et al. 2003).

The core of RISC is composed of one of four human Argonaute proteins (Agol-Ago4), associated with several cofactors like Dicer, Hsp90, and double stranded RNA-binding proteins: TRBP and/or PACT (protein activator of dsRNA-activated protein kinase) (Pare et al. 2009; Noland and Doudna 2013). These cofactors are important for loading of the miRNA duplex. Loading of the miRNA duplex is a process of activation RISC with assistance of Hsp90 mediating conformational changes of Ago, which allows miRNA duplex to enter the RISC (Pare et al. 2009; Gu et al. 2011). Maturation of RISC begins with unwinding the duplex. In the case of siRNAs, which are typical for almost complete base-paired stem, the unwinding process is characterized by immediate destroying the passenger strand; but for miRNA duplexes, cleavage step is bypassed because of the multiple mismatches for miRNA/miRNA*, which probably inhibit the act of cleaving (Matranga et al. 2005). This bypass mechanism in processing the miRNAs is executed by all known mammalian Ago proteins.

Presumably, a duplex functional asymmetry is crucial in determination of leading or guide (executive) strand and passenger strand. Thermodynamic stability and weaker base pairing relative to the other strand are supposed to be the key regulating factors. Strand with weaker interaction at the $5^{\prime}$ end will become more frequently the leading strand. It has been suggested that the weaker interaction enables the Ndomain of Ago to initiate more easily the unwinding process of duplex (Schwarz et al. 2003; Krol et al. 2004). Moreover, the guide strand usually starts with uracil base at the $5^{\prime}$ end and is typical for excess with purines (A/G) (Hu et al. 2009).

After incorporation of duplex and strand selection, RISC complex mediates the miRNA induced silencing. Whole miRNA sequence shows only partial complementarity with its targets. RISC complex presents only part of it, the 2-8nt sequence called the seed sequence (with high complementarity to $\mathrm{mRNA}$ ), and subsequently proceeds with down-regulation of gene expression that includes two processes: translation repression and/or mRNA cleavage. After cleaving of mRNA, the miRNA is not destroyed and can interfere with another target (Hutvagner and Zamore 2002).

\section{Regulation of miRNA biogenesis}

Although, there is growing evidence that miRNAs regulate up to $1 / 3$ of gene expression, much less is known about the regulation of miRNA production.

Knockouts of Drosha, DGCR8, Dicer and Argonaute protein. Several knockouts of key enzymes, involved in biogenesis of miRNAs, have been generated 
that helped to understand some of miRNA functions in the organism. The DGCR8 protein (cofactor for Drosha), a component of microprocessor complex, has been found to be essential for the miRNA biogenesis. Knockout of $d g c r 8$ gene in mouse embryos and embryonic cells cause impaired differentiation and development (Wang et al. 2007).

Drosha activity is essential for the survival in mice (Fukuda et al. 2007). Conditional Drosha and Dicer knockouts mice line, with inactivated Drosha and Dicer in spermatogenic cells, were infertile. Separate disruption of Drosha appeared to have more severe effect on spermatogenesis and fertility compared to Dicer inactivation in this model (Wu et al. 2012).

Homozygote mutation of dicer gene is lethal. Homozygous knockout embryos die after $12^{\text {th }}$ day of gestation, showing strongly impaired angiogenesis (Yang et al. 2004). Specific loss of Dicer in various organs and cell lines has confirmed a significant role of Dicer in normal development or physiological functions, e.g. morphogenesis of limp, myocardium, retina, thyroid, hippocampus, cortex, and many others (Harfe et al. 2005; Murchison et al. 2007; da Costa Martins et al. 2008; Davis et al. 2008a; Georgi and Reh 2010; Frezzetti et al. 2011). While Dicer is necessary for oocyte maturation, conditional knockout of DGCR8 that is specifically required for miRNAs processing, did not affect the production of oocytes (Suh et al. 2010). Effects of miRNA-reduced synthesis were observed also in Drosha and Dicer deficient endothelial cells. Silencing of Dicer expression in the endothelial cells caused decreased migration of cells and angiogenesis. The effect of Drosha silencing in the endothelial cells was less severe in vitro and totally disappeared in vivo (Kuehbacher et al. 2007). It is important to note that Dicer is also involved in the biogenesis of siRNA, so physiological impairment in Dicer-deficient cells or organism may be due to suppressed production of other interfering RNAs.

Although family of Argonaute proteins includes key enzymes involved in miRNA biogenesis and machinery, only knockout of one of its members - Ago2 has been found to be lethal early in the embryonic development (Morita et al. 2007). Ago2 also plays a crucial role in the proper slicing of the blood specific miRNAs, involved in erythropoiesis (Cheloufi et al. 2010). The specific loss of both Agol and Ago2 in the skin leads to a decreased expression of miRNAs and severe defects in the skin morphogenesis (Wang et al. 2012).

Regulation of miRNA transcription and processing. Core transcriptional enzymes of miRNA primary transcripts are widely expressed and they are not likely to be limiting regulatory step. There have been identified many miRNAs transcription factors, e.g. p53, c-myc, MEF2, and REST. Tumor suppressor p53 is known to activate miR-34a-c cluster, involved in regulation of cell cycle and carcinogenesis (He et al. 2007; Raver-Shapira et al. 2007). c-myc is other well established oncogenic protein that has been shown to stimulate or repress the expression of various miRNAs, e.g. c-myc activates miR-17-92 cluster transcription by binding to E-boxes. On the other hand, c-myc inhibits expression of several other miRNAs (e.g. miR-22, miR-26a, miR-29c) (Chang et al. 2008). The expression of miR-7 in the Drosophila eye is activated during photoreceptor differentiation owing to suppressed transcriptional factor Yan that represses miR-7 transcription in non-differentiated cells. miR-7 negatively regulates expression of Yan in differentiated cells. In this way, miR-7 and Yan form double-negative transcriptional feedback loop (Li and Carthew 2005).

While regulation of miRNA transcription determines the level of precursor's forms, it is important to realize that precursor levels do not always match with the levels of mature miRNAs (Zhang and Zeng 2010). Some post-transcriptional regulatory mechanisms became known owing to studies aimed on changes in miRNA expression during the development. miRNA expression profile is changing during the ontogeny. Only few miRNAs are expressed in early embryos. The number of expressed miRNAs continuously increases and culminates during the adulthood. From the ratio of primary transcript and mature forms of some miRNAs during the development, it has been suggested that regulation can occur in the Drosha regulatory step (Thomson et al. 2006). According to a correlative study, comparing the expression of precursor and mature miRNA, there are following categories:

1. precursor and mature miRNAs correlates, e.g. miR-100, miR-155, miR-125a;

2. correlation between precursor and mature miRNA is limited to some tissues or cell lines, e.g. miR-9, miR-1 and miR-216;

3. expression of mature miRNA is running in certain cells lines/tissues, while precursor is expressed in all or most tissue cells;

4. both mature as well as precursor miRNA are not expressed (Lee et al. 2008).

In vitro studies have confirmed differences between precursor and mature miRNAs. Lipopolysaccharide induced pre-miR-155 expression in human monocytes, achieved maximal levels $2 \mathrm{~h}$ after admin- 
istration, while expression of mature miR-155 peaked $9 \mathrm{~h}$ later. Concentration of mature miRNA was higher compared to pre-miRNA that can be explained by differences in their turnover. It has been suggested that pre-miRNAs are degraded earlier than miRNAs. However, the way in which levels of pre-miRNAs and miRNAs are regulated can differ, depending on tissue and particular miRNA (Schmittgen et al. 2008).

In some cases, miRNAs are present as precursors, but the mature forms are missing. It has been reported that Drosha cleaves miRNAs with different efficiency under in vitro conditions and this can be positively correlated with levels of mature miRNAs in vivo. Protein DGCR8 has been shown to have major stabilizing effect on Drosha via interaction with its middle domain and Drosha can regulate, vice versa, the activity of DGCR8. Therefore, a balance between activities of these two proteins to keep miRNAs cropping fluent has to be achieved. Efficiency of Drosha cleavage of particular pri-miRNA is indicated by several features, such as flexible or large terminal loop region and flanking single stranded RNA regions (Feng et al. 2011). In addition, other specific and non-specific control mechanisms of Drosha activity have been described. The first, well-known miRNA specific regulator is RNA binding protein Lin-28 and his homologue Lin-28B that down-regulates maturation of let-7 by inhibiting its cleavage step by Drosha. Lin28 induces uridylation of precursor let-7 that cannot be cleaved by Drosha and is degraded. It has also been shown that translation of Lin-28 is inhibited by let-7 that closes double negative feedback loop (Heo at al. 2008; Newman et al. 2008). Tumor suppressor BRCA1 has been found to enhance the activity of Drosha by direct interaction (Kawai and Amano 2012). Group of proteins SMAD through interactions with BMP/TGF- $\beta$ stimulate Drosha processing of miR-21 in vascular smooth muscle cells (Davis et al. 2008b). It has been shown that some mature miRNAs (e.g. miR-709) are capable negatively affect Drosha processing of other miRNA cluster (miR-15a/16-1). These findings suggest that miRNAs can also contribute, except of target regulation in the cytoplasm, to the regulation of biogenesis, occurring in the nucleus (Tang et al. 2012).

Regulation of miRNA processing occurs also at the level of Dicer activity. Dicer accumulation in the cytoplasm is dependent on the Dicer partner TRBP and TRBP knockout causes Dicer destabilization and premiRNA processing impairment (Melo et al. 2009). It has previously been described that Lin-28B blocked Dicer processing of let-7 (Heo et al. 2008). let-7 and miR-107 can affect Dicer and potentially influence the processing of its own precursors forms (Forman et al. 2008).

Once miRNA and the functional RISC complex are generated, miRNA appears to be surprisingly stable. Functional RISC complex can regenerate and catalyze cleaving of another target. Therefore, it is not limiting factor for miRNA-mediated regulation (Gregory et al. 2005). Since association of miRNA with Ago have protective effects against destruction by nucleases, Ago proteins can increase the abundance of mature miRNAs (Diederichs and Haber 2007; Zhang et al. 2012). miRNA recycling is believed to be regulated by the target posttranscriptional modification of miRNA and decrease of its stability (Baccarini et al. 2011). It has been suggested that complementarity of miRNA and their targets can trigger miRNA degradation. miRNA can be found in P-bodies. It is still not known whether this is a way to inactivate miRNAs or to store them (or both) (Parker and Sheth 2007).

Circadian regulation. Based on evidence from several species, including $A$. thaliana, D. melanogaster, and mouse models, a rhythmic control of miRNA expression is conserved from plants to mammals.

The circadian system regulates at least two miRNAs in D. melanogaster (miR-263a and miR-263b) with a rhythmic pattern that was abolished in arrhythmic clock mutant cyc01 (Yang et al. 2008). A daily variation of miR-16 and miR-181 expression has been observed in human leukocytes with the maximum in the middle of the light phase. A rhythm of miR-96 and miR-182 expression in mouse retina and a weak rhythm of miR-16, miR-20a, miR-141 show maximum in the light phase in rat's intestine (Xu et al. 2007; Balakrishnan et al. 2010; Figueredo et al. 2015).

Beside the evidence of the existence of circadian regulation of specific miRNAs, there exists also knowledge about the circadian variation of core enzymes that control miRNA biogenesis. According to Yan et al. (2013), Dicer shows a diurnal pattern of expression in the suprachiasmatic nuclei (SCN), retina, liver, and bone marrow that disappeared or weakened during aging or diabetes in mammals.

Evidence supporting the reciprocal regulatory relationship between miRNA and circadian system is growing. miR-219 and miR-132 show a distinct daily rhythm in mice SCN with higher expression during the light phase of light:dark cycle. Expression of miR132 has been proved to be light inducible via MAPK/ CREB dependent mechanism. Administration of miR-132 antagomirs showed that miR-132 negatively modulated the light entrainment. miR-219 is controlled via circadian oscillator by CLOCK/BMAL 
heterodimer binding to E-box found in its promoter region. Down-regulation of miR-219 lengthens the circadian period of free running activity in mice (Cheng et al. 2007). These authors have identified miR-219 and miR-132 as modulators of CLOCK/ BMAL1 dependent per1 transcription.

miR-494 and miR-152 have been found to be rhythmic in bimodal fashion in mouse serum and miR-494 post-transcriptionally repressed bmall expression under in vitro conditions (Shende et al. 2011). All three period genes are validated target genes for cluster miR-192/194 (Nagel et al. 2009). Another study has revealed post-transcriptional regulation of cryptochrome1 by miR-185. The protein level of CRY closely corresponds with antiphase of cytosolic level miR-185 (Lee et al. 2013). These findings suggest that miRNAs may play a role in the regulation of the expression of clock genes and influence the circadian system (Shende et al. 2011).

\section{How to identify miRNA target?}

Since number of newly identified miRNAs is constantly growing, the number of their possible targets is increasing, as well. Crucial importance is to recognize the biologically relevant interactions. So far, there are no strict rules to determine what kind of evidence is sufficient. In the present review, we provide a few examples of recently used validations of $\mathrm{miRNA} / \mathrm{mRNA}$ interactions.

\section{Computational prediction of miRNA targets}

Research focused on miRNA is recently supported by several useful databases. One of the most accessed and constantly upgraded is the database of miRNA sequences miRBase available at web page http://www. mirbase.org/_(Griffiths-Jones et al. 2006).

Hundreds of miRNA have been described with use of high throughput sequencing. Our capacity to understand their functions strongly depends on our potential to discover targets of particular miRNA. Mammalian targets can be predicted by searching for conserved 7nt matches in the $3^{\prime}$ UTRs regions complementary to miRNA so-called "seed" sequence. Seed sequence is a region between nucleotides 2 and 8 at the $5^{\prime}$ end of the miRNA with high complementary sequence to mRNA. Complementarity of seed sequence in the central and $3^{\prime}$ end is frequently incomplete (Lewis et al. 2005). mRNA motifs that match miRNA should be more evolutionary conserved compared to motifs with the same abundance in the same UTR that do not match miRNA sequence. Ratio of positive identification of miRNA/mRNA target is than 3.5:1. Profiling mRNA and miRNA studies have indicated that mRNA targeting can frequently occur on non-conserved sites, as well. Therefore, this approach is recently used as well, although this opinion has opponents. Except the above mentioned features, there are some additional rules to look for miRNA targets: 1) distance at least $15 \mathrm{nt}$ from the stop codon within 3'UTR region; 2) avoiding of positioning in the center of long UTRs; 3 ) take into account site accessibility e.g. AU-rich nucleotide sequence, near the suggested site; 4) presence of sites for coexpressed miRNAs in neighborhood; 5) to avoid complex RNA secondary structures and 6) free energy $(\Delta G)$ of the 70 nucleotides around $5^{\prime}$ and $3^{\prime}$ end of predicted miRNA binding site (Kuhn et al. 2008; Bartel et al. 2009). miRNA interfering sites can be estimated with help of several freely accessible databases. The rules mentioned above are preferentially useful for picking up an experimental target for further validation.

Databases for search of mammalian miRNA interferences (adapted from Bartel et al. 2009).

Site conservation considered:

- TargetScan (stringent seed pairing) - http:// targetscan.org/

- PicTar (stringent seed pairing for at least one of the sites for the miRNA) - http://pictar. mdc-berlin.de/

- Miranda (moderately stringent seed pairing) http://www.microrna.org/

- miRBase Targets (moderately stringent seed pairing) - http://microrna.sanger.ac.uk

- $\quad$ PITA Top (moderately stringent seed pairing) - $\quad$ http://genie.weizmann.ac.il/pubs/mir07/ mir07_data.html

- Site conservation not considered:

- TargetScan (stringent seed pairing) - http:// targetscan.org

- PITA All (moderately stringent seed pairing) - $\quad$ http://genie.weizmann.ac.il/pubs/mir07/ mir07_data.html

\section{Identification of miRNA/mRNA interactions}

To identify miRNA/mRNA interactions is possible by using antibodies against proteins associated with miRNA/mRNA complex, e.g. proteins creating RISC. miRNA and particular 3'UTR region coimmunoprecipitate with antibody targeted protein.

Technique based on the ribonucleotide immunoprecipitation, as described by Hassan et al. (2010), identifies miRNA target from polysomal extract after ribonucleotide immunoprecipitation. Polysomal ex- 
tract was prepared from preosteoblast cell line. Immunoprecipitation with Ago2 or GW182 antibody coupled to agarose beads was followed by release of ribonucleotide complex from beads and Trizol extraction of RNA. cDNA was synthesized from isolated RNA by using miRNA seed specific primer. PCR amplification was performed with primers designed to match upstream 3'UTR region of computationally predicted mRNAs to be targets of miRNA (used for design of reverse transcription primer).

Interaction of miRNA/mRNA can also be detected by using the biotinylated miRNA mimics. After transfection, modified miRNA cells are harvested $24 \mathrm{~h}$ later and complexes of biotinylated RISC and mRNA are pulled down with streptavidin-coated magnetic beads. Samples influenced by miRNA can be compared to total mRNA isolated from control cells by array (Lal et al. 2011).

Another approach describes a cell system using generation of cDNA library, derived from oligo dT primed total RNA, isolated from tissue of interest. p3TKzeo plasmid encoding a thymidine kinasezeocin fusion protein is used to perform dual-selection of sells. The 3'UTR-enchriched plasmid library is transfected into cells that do not express miRNA of interest. Cells expressing 3'UTR sequence can be selected by zeomycin. Zeomycin resistant cells are than transfected by miRNA. If miRNA silences 3'UTR region, thymidine kinase expression should be inhibited and cells with miRNA/mRNA interaction can be selected by ganciclovir. Cells producing thymidine kinase in the presence of ganciclovir will not survive. Ganciclovir selected clones can be after amplification sequenced. In this way, it is possible to reveal new miRNA targets without any information about mRNA sequence or computational prediction (Gaken et al. 2012).

\section{Measurement of miRNA interference end product}

There are many ways how to measure the product of the hypothesized miRNA target. It is possible to measure mRNA as well as protein product of mRNA. Coexpression is an obvious prerequisite of miRNA/ mRNA interaction, but it is important to remind that miRNAs usually target several mRNAs and final effect on transcriptome can be mediated via several regulatory steps. Therefore, this validation requires additional tests.

Measurement of miRNA expression is described in detail in the next paragraph. mRNA is most frequently measured by real time PCR, as designed by user or purchased assays. Several commercial tools are available to profile mRNA by real-time PCR expression using 96 or 384 platform, allowing monitoring many possible miRNA targets simultaneously (Qiagen, Thermo Fisher).

To visualize the expression of miRNA at the localization, when target mRNA is abundant, is possible by in situ hybridization. This technique allows studying the intracellular distribution of miRNA within physiological concentrations. Digoxigenin-labeled antisense miRNA probes are commercially available. Probe bound to the target is visualized by using digoxigenin antibody conjugated to alkaline phosphatase. It is also possible to perform in situ reverse transcription and PCR to amplify signal (Kuhn at el. 2008).

The Western blotting is the most usual way to measure the effect of miRNA on the concentration of the mRNA protein product. ELISA (enzyme-linkedimmunosorbent assay) is an alternative to Western analysis.

\section{Evaluation of miRNAs effects on physiological function}

Cell cultures are most often used to prove physiological effect of miRNA on intracellular process. To validate the predicted miRNA/mRNA interaction, reporter systems are frequently utilized. 3'UTR of studied mRNA is cloned downstream of the luciferase or green fluorescent protein open reading frame in the appropriate reporter plasmid. The complete sequence of $3^{\prime} \mathrm{UTR}$ region should be tested to assure that other sequences possibly influencing binding of miRNA are not present in the plasmid.

The recombinant plasmid and candidate miRNA are transiently transfected into the cells that do not produce studied RNAs. After transfection of miRNA into the cell (e.g. with Lipofectamine or similar product), a Luciferase reporter construct, containing desired 3'UTR region with miRNA binding site, can be used to monitor the activity of the regulated gene. Signal produced by reporter gene is measured $24-48$ $\mathrm{h}$ after the transfection. There is commercially available collection of 12000 human 3'UTR luciferase reporter clones that are transfection-ready (SwithGear Genomics).

Function can be further validated by overexpression of miRNA or miRNA mimics. miRNA mimics are commercially available chemically modified double-stranded RNAs that mimic the function of endogenous miRNAs. Effect of miRNA can also be tested by introducing of mutation into seed sequence miRNA or 3'UTR region of target mRNA (Kuhn et al. 2008; 
Vasudevan 2012). Lately, sponge mRNAs are being used to inhibit specifically the activity of whole family of miRNAs with the same seed sequence. Sponge mRNAs contain multiple target sites complementary to miRNA of interest and by binding to miRNAs inhibit their function (Ebert and Sharp 2010). Antagomirs represent another class of newly developed tools for modulating miRNA function. Antagomirs are chemically modified single-stranded RNA analogues complementary to miRNA that cause silencing.

Interaction of reporter plasmid containing $3^{\prime} \mathrm{UTR}$ region of gene of interest and miRNA are analyzed in supraphysiological concentrations. Therefore, other techniques are usually used in combination with reporter system.

Changes in target mRNA should be accompanied by a change in some physiological function. The most frequently used techniques monitor cell proliferation, differentiation, cell death, cell migration, production of some metabolite, enzyme or signal molecule, etc.

The efficient and easily incorporable way to validate the role of miRNA in the cell cycle regulation is the measurement of BrdU incorporation that can be after appropriate staining analyzed by microscopy or flow cytometry. Mitotic index can be determined by measurement of phosphorylated histone $\mathrm{H} 3$ and appropriate staining by the cytometry (Yang et al. 2015).

Studies focused on the physiological processes affected by miRNA require a mammalian experimental model. A novel approach, based on strongly different transcriptome of mRNA and miRNA of two mice strains (C57BL/6 and SPRET/Ei), has been used to validate the function of miRNA (Timmermans et al. 2015). Plasmid containing tested miRNA was injected hydrodynamically into the tail vein. It has been previously reported that miRNA plasmid injection in this way causes its overexpression mainly in the liver with peak expression after $8 \mathrm{~h}$ (Liu et al. 1999). Based on the differences between C57BL/6 and SPRET/Ei transcriptomes candidate, miRNAs have been used to influence mRNA expression in the liver of SPRET/ Ei mice. This approach was successful.

\section{Knockouts of miRNAs}

The generally used approach of the physiological function validation is a gene knockout under in vivo conditions. Since position of miRNAs is usually known, it is possible to perform knockout of a particular miRNA.

Several miRNAs have been identified that are essential for the development and their deletion may cause embryonic lethality. One of the first indispens- able miRNAs described were miR-1-1/miR-1-2 or cluster miR-17-92. Deletion of these miRNAs causes a prenatal death, mainly due to the cardiac and lung impaired development. Target knockout of endothelial specific miR-126 caused 50\% lethality and surviving mice displayed defects in the angiogenesis and vascular integrity (Park et al. 2010). Some miRNAs are present in mammals as duplicates or homologues, which in specific cases could be the reason for the functional redundancy. Functional redundancy has been shown in mice lacking either miR-133a-1 or miR-133a-2 that did not show pathology. However, double deletion of both miRNAs is connected with lethal heart defects and heart failure in one-half of the monitored cases (Liu et al. 2008).

Cluster miR-17-92 has been also found to be essential for lung and B-cell development. Mice with knockout of this cluster died soon after birth. However, mice lacking cluster miR-106a-363 or miR106b-25 were viable with no abnormalities. Triple deletion of miR-106a-363, miR-106b-25 and miR-1792 caused even more severe effects compared to those observed in single miR-17-92 knockouts. This study suggests that interactions between above-mentioned clusters can influence physiological processes (Ventura et al. 2008).

Other deletion study has revealed a role of miRNAs in the aorta morphology. It has been demonstrated that specific loss of miR-143 and miR-145 may induce morphological changes in the aorta. miR143 and miR-145 have previously been confirmed as down-regulated in human aortic aneurysms (Elia et al. 2009). In mice, deletion of pancreas specific miR375 caused impaired glucose homeostasis, hyperglycemia, and increased gluconeogenesis. The mice exhibited elevated total pancreatic alpha-cell numbers and slightly decreased beta-cell mass (Poy et al. 2009). Cartilage specific miR-140 was also examined in the knockout experiments. Young mice with deletion of miR-140 showed only mild skeletal phenotype with short stature and low body weight. However, miR140 knockout caused accelerated onset of age-related changes, such as proteoglycan loss and fibrillation of articular cartilage characteristic for osteoarthritis (Miyaki et al. 2010).

\section{What is the most suitable way to de- tect and evaluate miRNA?}

Laboratories with good laboratory practice in RNase free work (e.g. https://www.qiagen.com/us/ resources/molecular-biology-methods/rna) can adapt methods required for miRNA studies quite 
easily. The use of miRNA requires generally the same laboratory conditions and equipment as for the work with RNA. There is a substantial difference in the size between the mature miRNA and mRNA. Because of differences in molecular weight between miRNA and mRNA, isolation of small RNAs may slightly differ from isolation of messenger or total RNA. However, reverse transcription requires specific modifications.

\section{Sampling and isolation}

miRNA analysis begins with a sampling. A gold standard in experimental research is that sample intended for RNA isolation is snap frozen in the liquid nitrogen immediately after tissue excision. Because of the growing trend to use miRNA in medicine, there is a strong effort to measure miRNA in samples taken from histological materials and biofluids. miRNAs are highly stable in formalin-fixed paraffin-embedded tissues (Nelson et al. 2004). They were successfully isolated from formalin-fixed and paraffin-embedded tissues with higher success compared to mRNA (possibly because of shorter sequence). Circulating miRNAs are frequently analyzed in the plasma and serum, where their levels correlate well (Mitchell et al. 2008). Endogenous miRNA has been reported to be surprisingly stable in plasma and serum (Chen et al. 2008). miRNA are transported in circulation bound to other molecules or packed in vesicles that protect them from degradation by high plasma RNase activity. It has been shown that measurement of miRNA in plasma is not influenced by $24 \mathrm{~h}$ lasting incubation at room temperature or eight freeze-thawing cycles. Artificially added naked miRNAs were degraded in plasma within 2 min (Mitchell et al. 2008). Since cells contain much more miRNA compared to plasma or serum, it is crucially important not to contaminate the biofluid sample by miRNA from cells. EDTA is preferred before heparin when plasma will be used for analysis. Aliquots should be stored under $-80^{\circ} \mathrm{C}$.

Several kits for miRNA isolation are commercially available (Burgos et al. 2013). Most of the companies, providing chemistry for gene expression studies in their portfolio, implemented also chemistry for miRNA measurement (e.g. Qiagen, Thermo Fisher, Roche and others). Most of these column-based systems employ phenol/guanidine-based lysis combined with binding of miRNA on silica-membrane or special glass fibers and elution of miRNA into 30-100 $\mu \mathrm{l}$ of RNase-free water after several washing steps. This procedure usually involves also removing of DNA and proteins from samples as well as miRNA dissolv- ing and possibility to concentrate sample, if it is needed. Column-based isolation may be especially good choice for isolation of circulating miRNAs, since it allows to scale up initial volume of sample with denaturing reagent up to $50 \mathrm{ml}$ and to concentrate yield in early steps. Thus, the final concentration of isolated miRNA can achieve the needed level. The lowest volume of fluid sample for miRNA extraction is around $200 \mu \mathrm{l}$ but the amount of miRNA extracted from this volume is not sufficient for profiling.

In spite of many advantages of this approach, the kits mentioned above are costly. Researchers routinely using TRI Reagent can easily adopt solution provided for miRNA isolation Tri-reagent alternative - RNAzol RT. Using of RNAzol RT is reliable and affordable option for experienced user. miRNAs are present also in standard Tri-reagent isolation but it is estimated that small RNAs make up less than $1 \%$ of total RNA and samples may not obtain concentration high enough to perform arrays although it can be sufficient for standard real-time PCR. Columnbased technology for mRNA isolation usually did not recover small RNAs. Another advantage of isolation with Tri-reagent or RNA-reagent is that it does not interfere with any method possibly employed afterwards. Yield of miRNA from tissues is usually sufficient for measurement of concentration by spectrophotometer. In order to control the extraction step, a synthetic miRNAs from another species can be added into the homogenate (Mitchell et al. 2008).

\section{Reverse transcription}

Precursor miRNA. Since sequences of primary precursor miRNA and precursor miRNA are longer compared to the mature miRNA, their reverse transcription allows employing specific primer as well as random hexamers. The gene-specific primer utilization has been reported to be much more effective compared to reverse transcription with random hexamer. Gene specific primers have been reported to be used in cocktail. This approach requires information about sequence of miRNA precursor and only known sequences are obtained by this way. On the other hand, it is a way to enrich specific miRNA in case of nonspecific signal in PCR or very rare miRNA (Schmittgen et al. 2004). Today, the interest is more focused on the mature miRNA.

Mature miRNA. Since sequences of mature miRNAs are very short, an elongation of isolated miRNAs proceeds reverse transcription, elongation is performed on 3' end of sequence and there are several ways how to realize it. 
Sequence specific reverse transcription uses linear or stem loop primer complementary to $3^{\prime}$ end of miRNA with a tag used later in PCR. There are differences between reverse transcription with linear and stem loop reverse primer. Linear primers are easier to design but transcribe mature as well as precursor miRNA. Stem loop primers show reduced binding to precursor miRNAs. A target-specific stem-loop reverse transcription uses and adapter to extend $3^{\prime}$ end of miRNA (Chen et al.2005). A stem loop primer with a short sequence complementarity to 3 ' end is hybridized to miRNA first and then reverse transcription is performed (this solution is commercially provided by Thermo Fisher). In this case, reverse transcription is target specific, but if properly designed, it can be optimized for multiplex reaction.

The most frequently used nonspecific reverse transcription applies adenylation of $3^{\prime}$ end (Shi and Chiang 2005). This may be done by using a poly(A) polymerase. miRNAs are then reverse transcribed with use of oligo-dT primers with 3' degenerate anchor and a universal tag sequence on $5^{\prime}$ end that is later used to amplify cDNA synthesized from miRNA in the real time PCR (this solution is commercially provided by Qiagen). This vendor offers also possibility to synthesize all small non-coding RNAs and mRNA, using existing poly(A) tail (mRNA) or poly(A) tail addition with slightly different set up. After this transcription, the PCR is performed with universal primer complementary to tag sequence, used in reverse transcription and specific sequence of particular miRNA.

Another approach uses T4 RNA ligase to attach covalently to $3^{\prime}$ end of miRNA linker adaptor, containing universal primer-binding sequence (Benes and Castoldi 2010). Using of T4 RNA ligase increases the specificity and efficiency of reverse transcription since T4 RNA ligase preferentially modify short ssRNAs.

Another way, how to perform universal reverse transcription, is based on $3^{\prime}$ poly(A) tailing and 5' ligation of an adaptor sequence. In this way, miRNA is extended on $3^{\prime}$ as well as $5^{\prime}$ end, by a known sequence. Then, the cDNA is preamplified with use of adapters to increase concentration of all mature miRNA in the sample. Specific miRNA can be measured afterwards by combination of two primers and probe (commercially provided by Thermo Fisher).

\section{Real time PCR}

Today, the most frequently used technique to measure miRNA expression is the real time PCR. It is known that dynamics of pre-miRNA and mature
miRNA differs and therefore, in some cases, it may be useful to measure both premature as well as mature miRNAs. To measure the expression of miRNA, precursor PCR primers can be designed on the $3^{\prime}$ and $5^{\prime}$ direction of the hairpin. If desired, a probe can be designed to anneal to loop portion of premature miRNA.

PCR of mature miRNA usually uses a universal tag added during reverse transcription (Figure 2). Vendors do not provide information about the sequence of primer used in reverse transcription.

Generally, there are two main strategies how to perform real time PCR of miRNA. Sybr green chemistry uses two primers - one universal and one miRNA specific (Figure 2A). Another approach relies on labeled probe used together with two unlabeled primers. In this technique, one primer primes adapter added during the reverse transcription and the second one is miRNA specific. Probe can be designed to partially align miRNA sequence or anneal to the sequence of adapter added during specific reverse transcription (Figure 2B) (Chen et al. 2005).

miRNAs are frequently occurring in isoforms. One way how to discriminate between highly homologues sequences is employment of TaqMan probe (Thermo Fisher) along with forward and reverse primers that can increase specificity of PCR product synthesis.

Normalization is always a tricky step in the gene expression analysis. Until the present, no miRNA has been identified with such a stable expression that could be claimed as a versatile normalizer. However, normalization is indispensable and therefore, there are resources recommending some candidates. miR16 is supposed to be most frequently expressed uniformly. For cell-free circulating miRNA, miR-142-3p, miR-638, RNU44, RNU48, and other have been used. In general, normalizer always has to be checked for the consistency after the measurement. When it is not satisfactory, another housekeeper has to be taken. Combination of normalizers can be set as reference. Stability of expression can be tested by several programs (e.g. BestKeeper) or by means of standard statistics. In some cases, samples are spiked with miRNA from another species that is not naturally occurring in the sample or one or combination of synthetic miRNAs. These normalizers are added during the isolation step. It allows normalization at the very last step by measuring concentration of the internal standard (van Rooij 2011; Hrustincova et al. 2015).

With digital PCR, it is possible to perform absolute quantification of miRNA molecules copies. In this technique, sample after amplification is partitioned into 20 000. Droplets containing at least one copy 


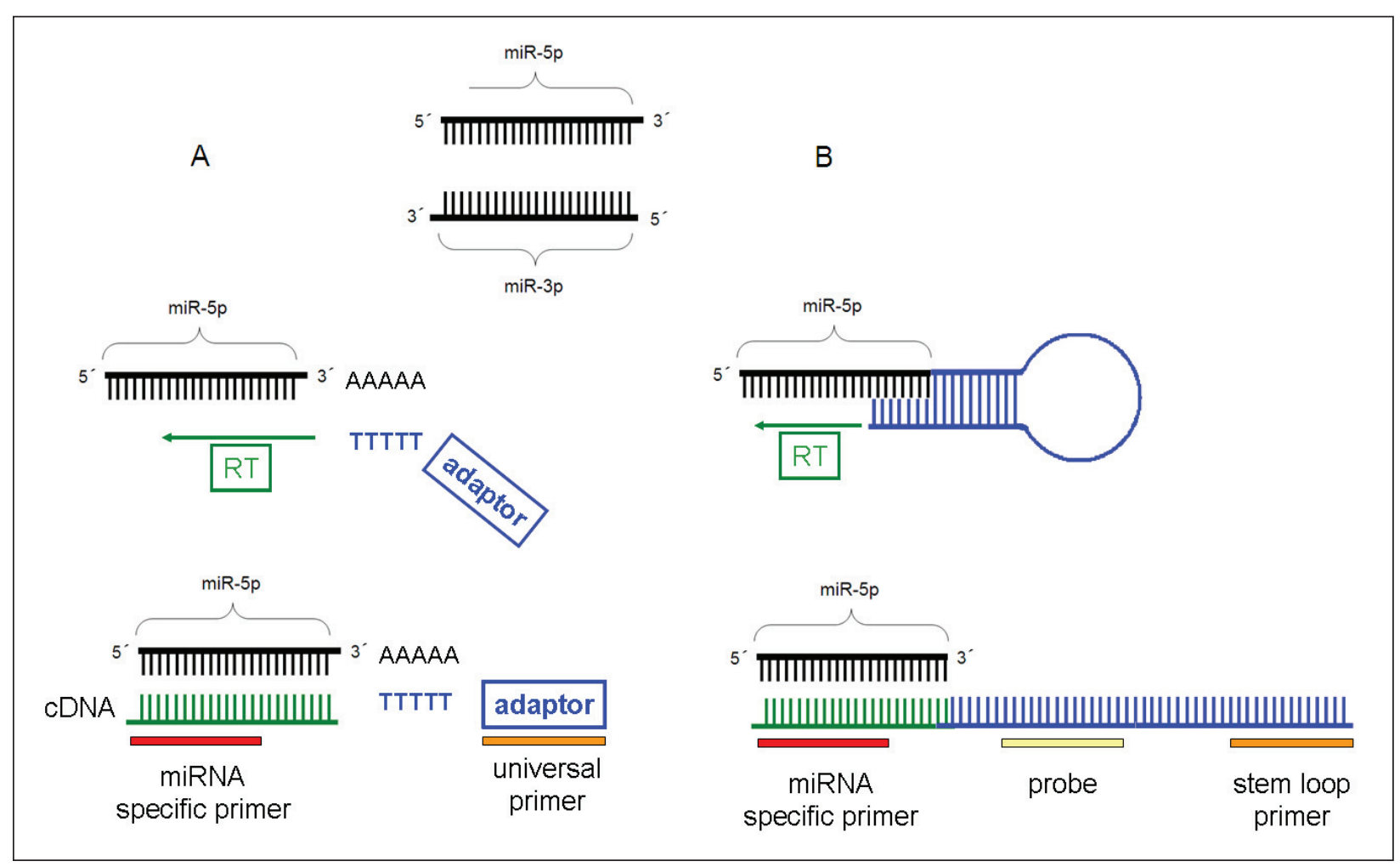

Figure 2. Two most frequent ways how to elongate mature miRNA during reverse transcription (RT). A) After polyadenylation of 3' end of mature miRNA, reverse transcription is performed with use of oligo dT primer with universal tag. Sequence of universal tag added during reverse transcription is used in PCR for priming by universal primer. miRNA specific primer binds to cDNA complementary to miRNA sequence. B) Stem loop primer with partial complementarity to $3^{\prime}$ end of mature miRNA transcribes miRNAs specifically. Sequence of stem loop primer is used for priming by labeled probe and reverse primer. Forward primer binds to cDNA complementary to miRNA.

of DNA are detected by fluorescence and scored as positive and droplets without fluorescence are scored as negative. Software calculates the concentration of target DNA as copies per microliter from the fraction of positive reactions using Poisson statistics. Normalization is still needed (according MIQE http://www. rdml.org/miqe.php).

Primer design. For experienced users, it may be more convenient to set up their own assay. This is accompanied by a need to design primers. Primer design differs strongly from that routinely used in standard PCR because of short sequence of miRNA and its similarity to precursors with partially identical sequence. Manual primer design is still employed. Since miRNA specific primer is too short for optimization of annealing temperature, a DNA tag added to forward and reverse primer can be used to achieve optimal PCR conditions after universal reverse transcription of miRNAs (Balcells et al. 2011). Spiking of primers by Locked Nucleic Acids to increase anneal- ing temperature has been not recommended by these authors because of lower PCR efficiency. Software solutions of miRNA primers design are also available (e.g. https://sourceforge.net/projects/mirprimer).

\section{Northern blot}

Before real time PCR, assays for miRNA measurement were developed a Northern blotting was widely used to measure miRNA expression. The major advantage of this approach was the measurement of primary precursor, precursor, and mature miRNA, on one blot. Sequence of miRNA can be obtained from database (e.g. miRBase) and reverse complementary probe can be ordered without any modification. Forward reaction with T4 polynucleotide kinase can be used for end labeling of the probe. After isolation and gel separation, miRNA is transferred to a membrane, hybridized with probe, and signal is visualized (van Rooij 2011). 


\section{Expression profiling}

Very popular way how to study miRNA is expression profiling. One approach is built up on the microarray technology (Agilent, Affymetrix). After miRNA isolation, T4 RNA ligase is used to attach the labeled nucleotides to the 3' end of miRNAs. Success of microarray analysis relay on the proper probe design. Since miRNAs sequences are short, probe design has limitations and melting temperature can vary from $45^{\circ} \mathrm{C}$ to $74^{\circ} \mathrm{C}$. Chemical modification of nucleotides is used to influence the hybridization affinity of probes and achieve optimal conditions for hybridization of many miRNAs probe duplexes (van Rooij 2011). Results obtained by microarray profiling are more useful for comparison of treatments or tissues to visualize changes in spectrum of miRNAs than for quantitative analysis. RNA input for microarray ranges from $100 \mathrm{ng}$ to $1 \mu \mathrm{g}$ that is one reason why their use has limitations in diagnostics based on biofluids. In experimental work, array output has to be validated by real time PCR.

Another approach employs real-time PCR profiling with use of 96 or 384 well plates. Since the number of miRNAs is counted in hundreds, whole spectrum of known miRNAs is possible to cover by this way. The PCR-based protocol has higher sensitivity and specificity compared to microarray one (Schmittgen et al. 2008). Real-time PCR profiler assays are now commercially available at least from two vendors (Qiagen, Thermo Fisher).

\section{Sequencing}

It is also possible to perform a deep sequencing to analyze miRNAs spectrum. Deep sequencing is based on the robust parallel sequencing that provides millions of reads from one sample. An input RNA for deep sequencing using Illumna platform ranges from $500 \mathrm{ng}$ to $5 \mu \mathrm{g}$ (Burgos et al. 2013). Sequencing is preceded by generation of small RNA library. During the first step, adapters to 3' and 5' end of miRNA are ligated. Double ligated miRNAs are reverse transcribed using RT primer hybridized to the 3 ' adapter, and in the next step, PCR amplification is performed. Generation of miRNA library is recently significantly improved and allows attaching of barcode directly to the sequence during PCR step (van Nieuwerburgh et al. 2011). Consequently, the library is run on a gel, size selected, and sequenced.

This technique allows discovery of new miRNAs because it measures absolute abundance of sequences. Since deep sequencing generates a huge volume of data, the number of copies of particular miRNA is determined digitally by free software tools (e.g. miRDeep2, miRanalyzer, SSCprofiler). A new sequence needs to meet a set of specific features to be recognized as miRNA. Newly found mature miRNA has to be long approximately 22nt, genome of interest has to include miRNA sequence, seed sequence should be phylogenetically conserved, and pre-miRNA sequence has to be able to create a hairpin structure (van Rooij 2011; Hrustincova et al. 2015).

\section{Interactions between miRNAs and hormones}

Giving a rising significance of miRNAs and their involvement in various biological processes, it is not surprising that they have been found to be implicated in development and function of endocrine system. miRNAs appear to play a role in synthesis (Dai et al. 2013; Robertson et al. 2013; Wu et al. 2015) and secretion (Poy et al. 2004; Plaisance et al. 2006) of several hormones. Expression of several miRNAs is under hormonal regulation ( $\mathrm{Hu}$ et al. 2013). miRNAs participate in molecular networks related to endocrine system disorders (Imbar and Eisenberg 2014).

\section{Adrenal gland}

Recent studies have reported involvement of some miRNAs in the adrenal gland processes. The end product of the renin-angiotensin system - angiotensin II (AngII) up-regulates the expression of miR-21 in human adrenocortical cells (H295R). From more than 200 miRNAs screenings, only miR-21 has been found to be up-regulated by AngII. miR-21 overexpression resulted in an increased aldosterone secretion and proliferation in H295R cells, suggesting that this miRNAs can down-regulate the expression of genes inhibiting the aldosterone secretion and cell proliferation. Authors have also shown that potassium (another secretagogue of aldosterone) had no modificatory effect on miR-21 expression, which makes miR-21 to be a possible specific target of AngII (Romero et al. 2008). Another study has demonstrated post-transcriptional effects of miRNA on the gene expression and corticosteroid production (Robertson et al. 2013). Release of corticosteroids from adrenal cortex is partly accomplished by strictly regulated expression of genes, which encode steroidogenic enzymes catalyzing their biosynthesis. 11-beta-hydroxylase (CYP11B1), responsible for the final conversion producing cortisol and aldosterone synthase (CYP11B2), plays an equivalent role in the production of aldosterone (Mornet et al. 1989). Knockdown of 
Dicerl by siRNA in human adrenocortical cell line resulted in a significant increase of CYP11B1 and CYPAAB2 mRNA. miR-24 has been shown to directly target CYP11B1 and CYP11B2 leading to decrease in aldosterone and cortisol productions. A considerable difference in miRNA expression profiles has been observed between normal adrenal tissue and aldosterone producing adenoma; miR-24 being down-regulated in adenoma (Robertson et al. 2013).

It has been proposed that adrenocorticotropic hormone (ACTH) stimulation may acutely affect the adrenal miRNA expression pattern and thereby modulate the adrenal response to acute stressors. miR-96, miR-101a, miR-142-3p, and miR-433 can repress glucocorticoid receptor $\mathrm{Nr} 3 \mathrm{cl}$ by binding to its 3' UTR in mouse adrenal glands (Riester et al. 2012).

$\mathrm{Hu}$ et al. (2013) have demonstrated that hormones can regulate miRNAs in the testis, ovary, and adrenal glands steroidogenic cells. Thus, miRNAs may be involved in the posttranscriptional/posttranslational regulation of steroidogenesis. miRNAs, which expression is up- or down-regulated in response to cAMP treatment, was identified in this study using MLTC-1 cells, a model cell line of Leydig cells, and rat granulosa cells. Treatment of cells with cAMP agonist caused an altered expression of several miRNAs: miRNA-212, miRNA-122, miRNA-27a, miRNA-466b, miRNA-200b, miRNA-138, miRNA-214, miRNA-183, miRNA-182, miRNA-132, miRNA-96 and miRNA-19a. Expression level of adrenal miRNAs appears to be regulated by more than one hormone. miRNA expression was studied by profiling in control rat adrenals and adrenals of rats treated with ACTH, 17-alpha-ethinyl estradiol (17a-E2) or synthetic glucocorticoid dexamethasone (DEX) in order to identify the altered miRNA expression in response to these hormones. Chronic ACTH treatment in vivo altered the levels of many miRNAs, whereas more miRNAs were up- than down-regulated. Significant differences have been observed in levels of 163 miRNAs between control adrenals and adrenals from 17a-E2-treated rats. DEX treatment caused changes in miRNA levels in both directions as well (Hu et al. 2013).

\section{Ovary}

Several recent studies have implicated miRNA role in ovarian development and function. miRNAs are associated with functional regulation of gonadal somatic and granulosa cells. miRNAs expressed in granulosa cells may directly affect the expression of specific genes, which are involved in the folliculogen- esis and ovarian steroidogenesis (Imbar and Eisenberg 2014).

miR-133 is involved in the follicle-stimulating hormone (FSH)-induced estrogen production. Foxl2 (Forkhead L2, a key modulator of steroidogenesis), expressed in ovarian granulosa cells, takes part in the steroidogenesis by regulating genes critical for the estrogen biosynthesis, such as StAR and Cyp19a1. In human and mouse granulosa cells, miR-133 inhibits Foxl2 expression by direct targeting its 3'UTR. Thereby, it impairs the negative Foxl2-mediated transcriptional regulation of StAR and Cyp19a1 and stimulates the estrogen production (Dai et al. 2013). It has been shown that cAMP induces miR-132 expression in mouse ovarian granulosa cells. miR-132 induces Cyp19a1 directly by suppressing the expression of an orphan nuclear receptor (Nurr1). Consequently, due to the up-regulation of Cyp19a1, the synthesis of estradiol is induced (Wu et al. 2015).

According to Yin et al. (2012), miR-383 promotes the estradiol (E2) release from granulosa cells by direct targeting the RNA binding motif single stranded interacting protein 1 .

\section{Testes and epididymis}

Numerous miRNAs, abundantly expressed in spermatogenic cells, play a role in the spermatogenesis. Androgens and FSH can act on Sertoli cells and regulate expression of miRNAs involved in the control of the cell adhesion pathways and male fertility (Wang and $\mathrm{Xu}$ 2015).

Ma et al. (2013) have suggested that miR-29a may play a vital role in the epididymal development and function owing to a regulatory impact on the androgen signaling pathway and miR-29a. miR-29a expression is repressed by androgen signaling via androgen receptor $(A R)$ in the mouse epididymis and vice versa, miR-29a influences AR expression via insulin-like growth factor 1 and p53 regulatory pathways. miR29a over-expression in transgenic mice resulted in epididymis hypoplasia.

\section{Endocrine pancreas}

A number of miRNAs play an important role in the islet physiology. They are involved in the regulation of beta-cell function (Poy et al. 2004; Ozcan 2014). They are implicated in the regulation of glucose homeostasis and can influence insulin levels by regulating its production, exocytosis or development of endocrine pancreas. Thereby, they may be important contributors to establishment of diabetes 
(Ozcan 2014).

miR-375 has been shown to negatively control the insulin secretion in pancreatic islets by targeting myotrophin. The mechanism of secretion modified by miR-375 is independent of changes in glucose metabolism and intracellular $\mathrm{Ca}^{2+}$ signaling; however, a correlation with direct influence on insulin exocytosis has been shown. Other targets of miR-375 may contribute to the regulation of insulin secretion (Poy et al. 2004). Another study has shown that over-expression of miR-9 inhibits insulin secretion induced by glucose or potassium in INS1E pancreatic beta cells. Results of this study support the idea that adequate miR-9 levels are essential to maintain appropriate levels of granuphilin (which negatively regulates insulin exocytosis) and optimal secretory capacity in insulin-producing cells. Expression of miR-9 target transcription factor Onecut-2 is reduced by the over-expression of miR-9. Silencing of Onecut-2 results in increased granuphilin expression and diminished insulin secretion in response to glucose (Plaisance et al. 2006).

The analysis of miR-7 expression in the fetal and adult human pancreas revealed that miR-7 is predominantly expressed in the endocrine cells of these structures. A coincidence was observed between increased miR-7 expression and a time of rise in hormone encoding genes (insulin, glucagon and somatostatin) during development. miR-7 is supposed to play a role in the endocrine pancreas development and endocrine cell differentiation (Correa-Medina et al. 2009).

\section{Hypothalamus and pituitary}

By using a deep sequencing technique, miRNA expression profiling of the mouse hypothalamus has been performed. Investigation of $\mathrm{miR}-24$ revealed its function as a regulator of oxytocin synthesis. miR-24 is abundant in hypothalamus and capable of inhibiting oxytocin production by targeting a sequence between the 3'UTR and coding sequence (Choi et al. 2013).

miR-375 is highly expressed in mouse pituitary and specifically located in the intermediate lobe. miR-375 is functioning as a mediator of the corticotropin-releasing factor (CRF) signaling pathway. It inhibits proopiomelanocortin (POMC) expression and affects the synthesis and secretion of pituitary hormones (Zhang et al. 2013). It has been proposed that some miRNAs can be implicated in stress-induced suppression of luteinizing hormone (LH) secretion. Stress-induced urocortin 2 (Ucn2) secretion, a member of CRF family, causes increased miR-325$3 p$ expression in rat anterior pituitary cells. Subsequently, miR-325-3p over-expression decreases the intracellular LH levels and suppresses LH beta-subunit translation and secretion (Nemoto et al. 2012).

miRNA seems to be directly involved in the regulation of gonadotropin synthesis by gonadotropinreleasing hormone $(\mathrm{GnRH})$. GnRH stimulation of FSHb (follicle-stimulating hormone, beta polypeptide) expression is dependent on miR-132/212 and involves a Sirtuin1-Forkhead Box O1 pathway. When blocking miR-132/212, total loss of FSH synthesis up-regulation appeared, proposing that this pathway is mandatory for $\mathrm{GnRH}$ activation (Lannes et al. 2015). GnRH induces expression of multiple miRNAs. Gene encoding miR-132 and miR-212 has been shown to be induced by GnRH. Downstream target of miR-132 and miR-212 - p250RhoGAP protein is involved in morphological changes and migration of L-betaT2 cells (immortalized gonadotrope cell line) (Godoy et al. 2011).

\section{miRNAs and cell proliferation modulated by hormones}

miRNAs participate in various endocrine malignancies, such as thyroid malignancies, gastrointestinal neuroendocrine malignancies, adrenocortical carcinomas, and pheochromocytoma (Kentwell et al. 2014). Wickramasinghe et al. (2009) have reported that E2 inhibits the expression of oncogenic miR21 in MCF-7 human breast cancer cells. Both alpha and beta estrogen receptors appear to contribute to miR-21 repression by E2. The decrease of miR-21 correlates with protein expression of its targets Pdcd4, PTEN and Bcl-2 (Wickramasinghe et al. 2009).

Eskildsen et al. (2013) have performed an analysis of miRNAs potentially involved in AngII-mediated hypertension in rats and hypertensive patients. miR-132 and miR-212 have been found to be highly increased in the heart, aortic wall, and kidney of rat with hypertension and cardiac hypertrophy following chronic AngII infusion. These miRNAs were also increased by activation of endothelin receptor - G-alpha q coupled receptor. A decrease in expression levels of miR-132 and miR-212 was found in human arteries from by-pass operated patients who were treated with angiotensin receptor type 1 blockers, while beta-blocker treatment did not exhibit any effect. Results from this study may suggest that miR-132 and miR-212 could be involved in AngII-induced Gq-signaling pathway leading to hypertension. 


\section{Conclusions and perspectives}

Research focused on the function and possible medical application of miRNAs is exponentially growing in all biomedical sciences, including endocrinology. Recent review provides a brief overview of recent knowledge about the mammalian non-coding RNA classes, including miRNAs, miRNAs discovery, nomenclature, and synthesis and actually applicable research strategies. miRNAs execute their functions by interference with 3'UTR region of regulated mRNA. It has been shown that there are several targets for one particular miRNA. In silico research in public databases allows to search for possible miRNAs targets in mammalian genomes. miRNA/mRNA interactions must be confirmed experimentally. Many of them are commercially available tools for miRNA investigation and miRNA/mRNA interactions validation. At present, the role of miRNAs is more fre- quently investigated under in vitro conditions, using cell proliferation, migration or viability as means to reveal mechanisms of miRNA functioning. These strategies have predominantly been employed in cancer-oriented research. miRNAs are investigated also in a complex system of integrative sciences, but this approach still lacks efficient techniques to deliver miRNAs into the organism and methods how to study miRNA signaling under in vivo conditions. In spite of the fact that a huge progress has been made in the identification of miRNAs functions in the regulation of several endocrine glands, including, pituitary, pancreas, testes, epididymis, ovary, adrenal gland and the hypothalamus.

\section{Acknowledgements}

This work was supported by grants VEGA 1/0499/15, APVV-0291-12 and APVV-14-0318.

\section{References}

Baccarini A, Chauhan H, Gardner TJ, Jayaprakash AD, Sachidanandam R, Brown BD. Kinetic analysis reveals the fate of a microRNA following target regulation in mammalian cells. Curr Biol 21, 369-376, 2011. http:// dx.doi.org/10.1016/j.cub.2011.01.067

Balcells I, Cirera S, Busk PK. Specific and sensitive quantitative RT-PCR of miRNAs with DNA primers. BMC Biotechnol 11, 70, 2011. http://dx.doi.org/10.1186/1472-6750-11-70

Balakrishnan A, Stearns AT, Park PJ, Dreyfuss JM, Ashley SW, Rhoads DB, Tavakkolizadeh A. MicroRNA mir-16 is anti-proliferative in enterocytes and exhibits diurnal rhythmicity in intestinal crypts. Exp Cell Res 316, 3512-3521, 2010. http://dx.doi.org/10.1016/j.yexcr.2010.07.007

Bartel DP. MicroRNAs: target recognition and regulatory functions. Cell 136, 215-233, 2009. http://dx.doi. org/10.1016/j.cell.2009.01.002

Benes V, Castoldi M. Expression profiling of microRNA using real-time quantitative PCR, how to use it and what is available. Methods 50, 244-249, 2010. http://dx.doi.org/10.1016/j.ymeth.2010.01.026

Berezikov E, Chung WJ, Willis J, Cuppen E, Lai EC. Mammalian mirtron genes. Mol Cell 28, 328-336, 2007. http:// dx.doi.org/10.1016/j.molcel.2007.09.028

Bernstein E, Caudy AA, Hammond SM, Hannon GJ. Role for a bidentate ribonuclease in the initiation step of RNA interference. Nature 409, 363-366, 2001. http://dx.doi.org/10.1038/35053110

Burgos KL, Javaherian A, Bomprezzi R, Ghaffari L, Rhodes S, Courtright A, Tembe W, Kim S, Metpally R, Van Keuren-Jensen K. Identification of extracellular miRNA in human cerebrospinal fluid by next-generation sequencing. RNA 19, 712-722, 2013. http://dx.doi.org/10.1261/rna.036863.112

Calado A, Treichel N, Müller EC, Otto A, Kutay U. Exportin-5-mediated nuclear export of eukaryotic elongation factor 1A and tRNA. EMBO J 21, 6216-6224, 2002. http://dx.doi.org/10.1093/emboj/cdf620

Chang TC, Yu D, Lee YS, Wentzel EA, Arking DE, West KM, Dang CV, Thomas-Tikhonenko A, Mendell JT. Widespread microRNA repression by Myc contributes to tumorigenesis. Nat Genet 40, 43-50, 2008. http://dx.doi. org/10.1038/ng.2007.30

Cheloufi S, Dos Santos CO, Chong MM, Hannon GJ. A dicer-independent miRNA biogenesis pathway that requires Ago catalysis. Nature 465, 584-589, 2010. http://dx.doi.org/10.1038/nature09092

Chen C, Ridzon DA, Broomer AJ, Zhou Z, Lee DH, Nguyen JT, Barbisin M, Xu NL, Mahuvakar VR, Andersen MR, Lao KQ, Livak KJ, Guegler KJ. Real-time quantification of microRNAs by stem-loop RT-PCR. Nucleic Acids Res 33, e179, 2005. http://dx.doi.org/10.1093/nar/gnil78 
Chen X, Ba Y, Ma L, Cai X, Yin Y, Wang K, Guo J, Zhang Y, Chen J, Guo X, Li Q, Li X, Wang W, Zhang Y, Wang J, Jiang X, Xiang Y, Xu C, Zheng P, Zhang J, Li R, Zhang H, Shang X, Gong T, Ning G, Wang J, Zen K, Zhang J, Zhang CY. Characterization of microRNAs in serum: a novel class of biomarkers for diagnosis of cancer and other diseases. Cell Res 18, 997-1006, 2008. http://dx.doi.org/10.1038/cr.2008.282

Cheng HY, Papp JW, Varlamova O, Dziema H, Russell B, Curfman JP, Nakazawa T, Shimizu K, Okamura H, Impey S, Obrietan K. MicroRNA modulation of circadian-clock period and entrainment. Neuron 54, 813-829, 2007. http://dx.doi.org/10.1016/j.neuron.2007.05.017

Chendrimada TP, Gregory RI, Kumaraswamy E, Norman J, Cooch N, Nishikura K, Shiekhattar R. TRBP recruits the Dicer complex to Ago2 for microRNA processing and gene silencing. Nature 436, 740-744, 2005. http:// dx.doi.org/10.1038/nature03868

Choi JW, Kang SM, Lee Y, Hong SH, Sanek NA, Young WS, Lee HJ. MicroRNA profiling in the mouse hypothalamus reveals oxytocin-regulating microRNA. J Neurochem 126, 331-337, 2013. http://dx.doi.org/10.1111/jnc.12308

Corcoran DL, Pandit KV, Gordon B, Bhattacharjee A, Kaminski N, Benos PV. Features of mammalian microRNA promoters emerge from polymerase II chromatin immunoprecipitation data. PLoS One 4, e5279, 2009. http://dx.doi.org/10.1371/journal.pone.0005279

Correa-Medina M, Bravo-Egana V, Rosero S, Ricordi C, Edlund H, Diez J, Pastori RL. MicroRNA miR-7 is preferentially expressed in endocrine cells of the developing and adult human pancreas. Gene Expr Patterns 9, 193-199, 2009. http://dx.doi.org/10.1016/j.gep.2008.12.003

da Costa Martins PA, Bourajjaj M, Gladka M, Kortland M, van Oort RJ, Pinto YM, Molkentin JD, De Windt LJ. Conditional dicer gene deletion in the postnatal myocardium provokes spontaneous cardiac remodeling. Circulation 118, 1567-1576, 2008. http://dx.doi.org/10.1161/CIRCULATIONAHA.108.769984

Dai A, Sun H, Fang T, Zhang Q, Wu S, Jiang Y, Ding L, Yan G, Hu Y. MicroRNA-133b stimulates ovarian estradiol synthesis by targeting Foxl2. FEBS Lett 587, 2474-2482, 2013. http://dx.doi.org/10.1016/j.febslet.2013.06.023

Davis TH, Cuellar TL, Koch SM, Barker AJ, Harfe BD, McManus MT, Ullian EM. Conditional loss of Dicer disrupts cellular and tissue morphogenesis in the cortex and hippocampus. J Neurosci 28, 4322-4330, 2008a. http:// dx.doi.org/10.1523/JNEUROSCI.4815-07.2008

Davis BN, Hilyard AC, Lagna G, Hata A. SMAD proteins control DROSHA-mediated microRNA maturation. Nature 454, 56-61, 2008b. http://dx.doi.org/10.1038/nature07086

Denli AM, Tops BB, Plasterk RH, Ketting RF, Hannon GJ. Processing of primary microRNAs by the Microprocessor complex. Nature 432, 231-235, 2004. http://dx.doi.org/10.1038/nature03049

Diederichs S, Haber DA. Dual role for argonautes in microRNA processing and posttranscriptional regulation of microRNA expression. Cell 131, 1097-1108, 2007. http://dx.doi.org/10.1016/j.cell.2007.10.032

Dogini DB, Pascoal VD, Avansini SH, Vieira AS, Pereira TC, Lopes-Cendes I. The new world of RNAs. Genet Mol Biol 37, 285-293, 2014. http://dx.doi.org/10.1590/S1415-47572014000200014

Ebert MS, Sharp PA. MicroRNA sponges: progress and possibilities. RNA 16, 2043-2050, 2010. http://dx.doi. org/10.1261/rna.2414110

Elia L, Quintavalle M, Zhang J, Contu R, Cossu L, Latronico MV, Peterson KL, Indolfi C, Catalucci D, Chen J, Courtneidge SA, Condorelli G. The knockout of miR-143 and -145 alters smooth muscle cell maintenance and vascular homeostasis in mice: correlates with human disease. Cell Death Differ 16, 1590-1598, 2009. http:// dx.doi.org/10.1038/cdd.2009.153

Eskildsen TV, Jeppesen PL, Schneider M, Nossent AY, Sandberg MB, Hansen PB, Jensen CH, Hansen ML, Marcussen N, Rasmussen LM, Bie P, Andersen DC, Sheikh SP. Angiotensin II regulates microRNA-132/-212 in hypertensive rats and humans. Int J Mol Sci 14, 11190-11207, 2013. http://dx.doi.org/10.3390/ijms140611190

Feng Y, Zhang X, Song Q, Li T, Zeng Y. Drosha processing controls the specificity and efficiency of global microRNA expression. Biochem Biophys Acta 1809, 700-707, 2011. http://dx.doi.org/10.1016/j.bbagrm.2011.05.015

Figueredo Dde S, Gitai DL, Andrade TG. Daily variations in the expression of miR-16 and miR-181a in human leukocytes. Blood Cells Mol Dis 54, 364-368, 2015. http://dx.doi.org/10.1016/j.bcmd.2015.01.004

Filipowicz W. RNAi: the nuts and bolts of the RISC machine. Cell 122, 17-20, 2005. http://dx.doi.org/10.1016/j. cell.2005.06.023

Fire A, Xu S, Montgomery MK, Kostas SA, Driver SE, Mello CC. Potent and specific genetic interference by doublestranded RNA in Caenorhabditis elegans. Nature 391, 806-811, 1998. http://dx.doi.org/10.1038/35888

Forman JJ, Legesse-Miller A, Coller HA. A search for conserved sequences in coding regions reveals that the let-7 microRNA targets Dicer within its coding sequence. Proc Natl Acad Sci U S A 105, 14879-14884, 2008. http:// dx.doi.org/10.1073/pnas.0803230105 
Frezzetti D, Reale C, Cali G, Nitsch L, Fagman H, Nilsson O, Scarfo M, De Vita G, Di Lauro R. The microRNA-processing enzyme Dicer is essential for thyroid function. PLoS One 6, e27648, 2011. http://dx.doi.org/10.1371/ journal.pone.0027648

Fukuda T, Yamagata K, Fujiyama S, Matsumoto T, Koshida I, Yoshimura K, Mihara M, Naitou M, Endoh H, Nakamura T, Akimoto C, Yamamoto Y, Katagiri T, Foulds C, Takezawa S, Kitagawa H, Takeyama K, O’Malley BW, Kato S. DEAD-box RNA helicase subunits of the Drosha complex are required for processing of rRNA and a subset of microRNAs. Nat Cell Biol 9, 604-611, 2007. http://dx.doi.org/10.1038/ncb1577

Gaken J, Mohamedali AM, Jiang J, Malik F, Stangl D, Smith AE, Chronis C, Kulasekararaj AG, Thomas NS, Farzaneh F, Tavassoli M, Mufti GJ. A functional assay for microRNA target identification and validation. Nucleic Acids Res 40, e75, 2012. http://dx.doi.org/10.1093/nar/gks145

Georgi SA, Reh TA. Dicer is required for the transition from early to late progenitor state in the developing mouse retina. J. Neurosci 30, 4048-4061, 2010. http://dx.doi.org/10.1523/JNEUROSCI.4982-09.2010

Godoy J, Nishimura M, Webster NJ. Gonadotropin-releasing hormone induces miR-132 and miR-212 to regulate cellular morphology and migration in immortalized LbetaT2 pituitary gonadotrope cells. Mol Endocrinol 25, 810-820, 2011. http://dx.doi.org/10.1210/me.2010-0352

Gregory RI, LaTP, Cooch N, Shiekhattar R. Human RISC couples microRNA biogenesis and posttranscriptional gene silencing. Cell 123, 631-640, 2005. http://dx.doi.org/10.1016/j.cell.2005.10.022

Griffiths-Jones S, Grocock RJ, van Dongen S, Bateman A, Enright AJ. miRBase: microRNA sequences, targets and gene nomenclature. Nucleic Acids Research 34, Database issue 140-4, 2006. http:/dx.doi.org/10.1093/nar/ gkj112

Gu S, Jin L, Zhang F, Huang Y, Grimm D, Rossi JJ, Kay MA. Thermodynamic stability of small hairpin RNAs highly influences the loading process of different mammalian Argonautes. Proc Natl Acad Sci U S A 108, 92089213, 2011. http://dx.doi.org/10.1073/pnas.1018023108

Han J, Lee Y, Yeom KH, Nam JW, Heo I, Rhee JK, Sohn SY, Cho Y, Zhang BT, Kim VN. Molecular basis for the recognition of primary microRNAs by the Drosha-DGCR8 complex. Cell 125, 887-901, 2006. http://dx.doi. org/10.1016/j.cell.2006.03.043

Harfe BD, McManus MT, Mansfield JH, Hornstein E, Tabin CJ. The RNaseIII enzyme Dicer is required for morphogenesis but not patterning of the vertebrate limb. Proc Natl Acad Sci U S A 102, 10898-10903, 2005. http:// dx.doi.org/10.1073/pnas.0504834102

Hassan MQ, Gordon JA, Lian JB, van Wijnen AJ, Stein JL, Stein GS. Ribonucleoprotein immunoprecipitation (RNP-IP): a direct in vivo analysis of microRNA-targets. J Cell Biochem 110, 817-822, 2010. http://dx.doi. $\operatorname{org} / 10.1002 /$ jcb. 22562

He L, Thomson JM, Hemann MT, Hernando-Monge E, Mu D, Goodson S, Powers S, Cordon-Cardo C, Lowe SW, Hannon GJ, Hammond SM. A microRNA polycistron as a potential human oncogene. Nature 435, 828-833, 2005. http://dx.doi.org/10.1038/nature03552

He L, He X, Lim LP, de Stanchina E, Xuan Z, Liang Y, Xue W, Zender L, Magnus J, Ridzon D, Jackson AL, Linsley PS, Chen C, Lowe SW, Cleary MA, Hannon GJ. A microRNA component of the p53 tumour suppressor network. Nature 447, 1130-1134, 2007. http://dx.doi.org/10.1038/nature05939

Heo I, Joo C, Cho J, Ha M, Han J, Kim VN. Lin28 mediates the terminal uridylation of let-7 precursor Micro- RNA. Molecular Cell 32, 276-284, 2008. http://dx.doi.org/10.1016/j.molcel.2008.09.014

Holley CL, Topkara VK. An introduction to small non-coding RNAs: miRNA and snoRNA. Cardiovasc Drugs Ther 25, 151-159, 2011. http://dx.doi: 10.1007/s10557-011-6290-z

Hock J, Meister G. The Argonaute protein family. Genome Biol 9, 210, 2008. http://dx.doi.org/10.1186/gb-2008-9-2-210

Hrustincova A, Votavova H, Dostalova Merkerova M. Circulating MicroRNAs: Methodological Aspects in Detection of These Biomarkers.Folia Biologica (Praha) 61, 203-218, 2015.

Hu HY, Yan Z, Xu Y, Hu H, Menzel C, Zhou YH, Chen W, Khaitovich P. Sequence features associated with microRNA strand selection in humans and flies. BMC Genomics 10, 413, 2009. http://dx.doi.org/10.1186/14712164-10-413

Hu Z, Shen WJ, Cortez Y, Tang X, Liu LF, Kraemer FB, Azhar S. Hormonal regulation of microRNA expression in steroid producing cells of the ovary, testis and adrenal gland. PLoS One 8, e78040, 2013. http://dx.doi. org/10.1371/journal.pone.0078040

Hutvagner G, Zamore PD. A microRNA in a multiple-turnover RNAi enzyme complex. Science 297, 2056-2060, 2002. http://dx.doi.org/10.1126/science.1073827

Imbar T, Eisenberg I. Regulatory role of microRNAs in ovarian function. Fertil Steril 101, 1524-1530, 2014. http:// dx.doi.org/10.1016/j.fertnstert.2014.04.024 
Kawai S, Amano A. BRCA1 regulates microRNA biogenesis via the DROSHA microprocessor complex. J Cell Biol 197, 201-208, 2012. http://dx.doi.org/10.1083/jcb.201110008

Kentwell J, Gundara JS, Sidhu SB. Noncoding RNAs in endocrine malignancy. Oncologist 19, 483-491, 2014. http:// dx.doi: 10.1634/theoncologist.2013-0458

Kim VN. MicroRNA biogenesis: coordinated cropping and dicing. Nat Rev Mol Cell Biol 6, 376-385, 2005. http:// dx.doi.org/10.1038/nrm1644

Krol J, Sobczak K, Wilczynska U, Drath M, Jasinska A, Kaczynska D, Krzyzosiak WJ. Structural features of microRNA (miRNA) precursors and their relevance to miRNA biogenesis and small interfering RNA/short hairpin RNA design. J Biol Chem 279, 42230-42239, 2004. http://dx.doi.org/10.1074/jbc.M404931200

Kuehbacher A, Urbich C, Zeiher AM, Dimmeler S. Role of Dicer and Drosha for endothelial microRNA expression and angiogenesis. Circ Res 101, 59-68, 2007. http://dx.doi.org/10.1161/CIRCRESAHA.107.153916

Kuhn DE, Martin MM, Feldman DS, Terry AV Jr, Nuovo GJ, Elton TS. Experimental validation of miRNA targets. Methods 44, 47-54, 2008. http://dx.doi.org/10.1016/j.ymeth.2007.09.005

Lal A, Thomas MP, Altschuler G, Navarro F, O’Day E, Li XL, Concepcion C, Han YC, Thiery J, Rajani DK, Deutsch A, Hofmann O, Ventura A, Hide W, Lieberman J. Capture of microRNA-bound mRNAs identifies the tumor suppressor miR-34a as a regulator of growth factor signaling. PLoS Genet 7, e1002363, 2011. http://dx.doi. org/10.1371/journal.pgen.1002363

Landthaler M, Yalcin A, Tuschl T. The human DiGeorge syndrome critical region gene 8 and Its D. melanogaster homolog are required for miRNA biogenesis. Curr Biol 14, 2162-2167, 2004. http://dx.doi.org/10.1016/j. cub.2004.11.001

Lannes J, L'Hote D, Garrel G, Laverriere JN, Cohen-Tannoudji J, Querat B. Rapid communication: A microRNA-132/212 pathway mediates GnRH activation of FSH expression. Mol Endocrinol 29, 364-372, 2015. http://dx.doi.org/10.1210/me.2014-1390

Lee RC, Feinbaum RL, Ambros V. The C. elegans heterochronic gene lin-4 encodes small RNAs with antisense complementarity to lin-14. Cell 75, 843-854, 1993. http://dx.doi.org/10.1016/0092-8674(93)90529-Y

Lee Y, Jeon K, Lee JT, Kim S, Kim VN. MicroRNA maturation: stepwise processing and subcellular localization. EMBO J 21, 4663-4670, 2002. http://dx.doi.org/10.1093/emboj/cdf476

Lee Y, Ahn C, Han J, Choi H, Kim J, Yim J, Lee J, Provost P, Radmark O, Kim S, Kim VN. The nuclear RNase III Drosha initiates microRNA processing. Nature 425, 415-419, 2003. http://dx.doi.org/10.1038/nature01957

Lee Y, Kim M, Han J, Yeom KH, Lee S, Baek SH, Kim VN. MicroRNA genes are transcribed by RNA polymerase II. EMBO J 23, 4051-4060, 2004a. http://dx.doi.org/10.1038/sj.emboj.7600385

Lee YS, Nakahara K, Pham JW, Kim K, He Z, Sontheimer EJ, Carthew RW. Distinct roles for Drosophila Dicer-1 and Dicer-2 in the siRNA/miRNA silencing pathways. Cell 117, 69-81, 2004b. http://dx.doi.org/10.1016/S00928674(04)00261-2

Lee EJ, Baek M, Gusev Y, Brackett DJ, Nuovo GJ, Schmittgen TD. Systematic evaluation of microRNA processing patterns in tissues, cell lines, and tumors. RNA 14, 35-42, 2008. http://dx.doi.org/10.1261/rna.804508

Lee KH, Kim SH, Lee HR, Kim W, Kim DY, Shin JC, Yoo SH, Kim KT. MicroRNA-185 oscillation controls circadian amplitude of mouse Cryptochrome 1 via translational regulation. Mol Biol Cell 24, 2248-2255, 2013. http:// dx.doi.org/10.1091/mbc.E12-12-0849

Lewis BP, Burge CB, Bartel DP. Conserved seed pairing, often flanked by adenosines, indicates that thousands of human genes are microRNA targets. Cell 120, 15-20, 2005. http://dx.doi.org/10.1016/j.cell.2004.12.035

Li X, Carthew RW. A microRNA mediates EGF receptor signaling and promotes photoreceptor differentiation in the Drosophila eye. Cell 123, 1267-1277, 2005. http://dx.doi.org/10.1016/j.cell.2005.10.040

Liu F, Song Y, Liu D. Hydrodynamics-based transfection in animals by systemic administration of plasmid DNA. Gene Ther 6, 1258-1266, 1999. http://dx.doi.org/10.1038/sj.gt.3300947

Liu N, Bezprozvannaya S, Williams AH, Qi X, Richardson JA, Bassel-Duby R, Olson EN. microRNA-133a regulates cardiomyocyte proliferation and suppresses smooth muscle gene expression in the heart. Genes Dev 22, 3242-3254, 2008. http://dx.doi.org/10.1101/gad.1738708

Ma W, Hu S, Yao G, Xie S, Ni M, Liu Q, Gao X, Zhang J, Huang X, Zhang Y. An androgen receptor-microrna-29a regulatory circuitry in mouse epididymis. J Biol Chem 288, 29369-29381, 2013. http://dx.doi.org/10.1074/ jbc.M113.454066

MacRae IJ, Zhou K, Li F, Repic A, Brooks AN, Cande WZ, Adams PD, Doudna JA. Structural basis for doublestranded RNA processing by Dicer. Science 311, 195-198, 2006. http://dx.doi.org/10.1126/science.1121638

Matera AG, Terns RM, Terns MP. Non-coding RNAs: lessons from the small nuclear and small nucleolar RNAs. Nat Rev Mol Cell Biol 8, 209-220, 2007. http://dx.doi.org/10.1038/nrm2124 
Matranga C, Tomari Y, Shin C, Bartel DP, Zamore PD. Passenger-strand cleavage facilitates assembly of siRNA into Ago2-containing RNAi enzyme complexes. Cell 123, 607-620, 2005. http://dx.doi.org/10.1016/j.cell.2005.08.044

Melo SA, Ropero S, Moutinho C, Aaltonen LA, Yamamoto H, Calin GA, Rossi S, Fernandez AF, Carneiro F, Oliveira C, Ferreira B, Liu CG, Villanueva A, Capella G, Schwartz S Jr, Shiekhattar R, Esteller M. A TARBP2 mutation in human cancer impairs microRNA processing and DICER1 function. Nat Genet 41, 365-370, 2009. http:// dx.doi.org/10.1038/ng.317

Mitchell PS, Parkin RK, Kroh EM, Fritz BR, Wyman SK, Pogosova-Agadjanyan EL, Peterson A, Noteboom J, O’Briant KC, Allen A, Lin DW, Urban N, Drescher CW, Knudsen BS, Stirewalt DL, Gentleman R, Vessella RL, Nelson PS, Martin DB, Tewari M. Circulating microRNAs as stable blood-based markers for cancer detection. Proc Natl Acad Sci U S A 105, 10513-10518, 2008. http://dx.doi.org/10.1073/pnas.0804549105

Miyaki S, Sato T, Inoue A, Otsuki S, Ito Y, Yokoyama S, Kato Y, Takemoto F, Nakasa T, Yamashita S, Takada S, Lotz MK, Ueno-Kudo H, Asahara H. MicroRNA-140 plays dual roles in both cartilage development and homeostasis. Genes Dev 24, 1173-1185, 2010. http://dx.doi.org/10.1101/gad.1915510

Monteys AM, Spengler RM, Wan J, Tecedor L, Lennox KA, Xing Y, Davidson BL. Structure and activity of putative intronic miRNA promoters. RNA 16, 495-505, 2010. http://dx.doi.org/10.1261/rna.1731910

Morita S, Horii T, Kimura M, Goto Y, Ochiya T, Hatada I. One Argonaute family member, Eif2c2 (Ago2), is essential for development and appears not to be involved in DNA methylation. Genomics 89, 687-696, 2007. http:// dx.doi.org/10.1016/j.ygeno.2007.01.004

Mornet E, Dupont J, Vitek A, White PC. Characterization of two genes encoding human steroid 11 beta-hydroxylase (P-450(11) beta). J Biol Chem 264, 20961-20967, 1989.

Murchison EP, Stein P, Xuan Z, Pan H, Zhang MQ, Schultz RM, Hannon GJ. Critical roles for Dicer in the female germline. Genes Dev 21, 682-693, 2007. http://dx.doi.org/10.1101/gad.1521307

Nagel R, Clijsters L, Agami R. The miRNA-192/194 cluster regulates the Period gene family and the circadian clock. FEBS J 276, 5447-5455, 2009. http://dx.doi.org/10.1111/j.1742-4658.2009.07229.x

Nelson PT, Baldwin DA, Scearce LM, Oberholtzer JC, Tobias JW, Mourelatos Z. Microarray-based, high-throughput gene expression profiling of microRNAs. Nat Methods 1, 155-161, 2004. http://dx.doi.org/10.1038/nmeth717

Nemoto T, Mano A, Shibasaki T. Increased expression of miR-325-3p by urocortin 2 and its involvement in stressinduced suppression of LH secretion in rat pituitary. Am J Physiol Endocrinol Metab 302, E781-E787, 2012. http://dx.doi.org/10.1152/ajpendo.00616.2011

Newman MA, Thomson, JM, Hammond SM. Lin-28 interaction with the Let-7 precursor loop mediates regulated microRNA processing. RNA 14, 1539-1549, 2008. http://dx.doi.org/10.1261/rna.1155108

Noland CL, Doudna JA. Multiple sensors ensure guide strand selection in human RNAi pathways. RNA 19, 639-648, 2013. http://dx.doi.org/10.1261/rna.037424.112

Okamura K, Hagen JW, Duan H, Tyler DM, Lai EC. The mirtron pathway generates microRNA-class regulatory RNAs in Drosophila. Cell 130, 89-100, 2007. http://dx.doi.org/10.1016/j.cell.2007.06.028

Ozcan S. Minireview: microRNA function in pancreatic $\beta$ cells. Mol Endocrinol 28, 1922-1933, 2014. http://dx.doi. org/10.1210/me.2014-1306

Ozsolak F, Poling LL, Wang Z, Liu H, Liu XS, Roeder RG, Zhang X, Song JS, Fisher DE. Chromatin structure analyses identify miRNA promoters. Genes Dev 22, 3172-3183, 2008. http://dx.doi.org/10.1101/gad.1706508

Pare JM, Tahbaz N, Lopez-Orozco J, LaPointe P, Lasko P, Hobman TC. Hsp90 regulates the function of argonaute 2 and its recruitment to stress granule and P-bodies. Mol Biol Cell 20, 3273-3284, 2009. http://dx.doi. org/10.1091/mbc.E09-01-0082

Park CY, Choi YS, McManus MT. Analysis of microRNA knockouts in mice. Hum Mol Genet 19, 169-75, 2010. http:// dx.doi.org/10.1093/hmg/ddq367

Parker R, Sheth U. P bodies and the control of mRNA translation and degradation. Mol Cell 25, 635-646, 2007. http://dx.doi.org/10.1016/j.molcel.2007.02.011

Plaisance V, Abderrahmani A, Perret-Menoud V, Jacquemin P, Lemaigre F, Regazzi R. MicroRNA-9 controls the expression of Granuphilin/Slp4 and the secretory response of insulin-producing cells. J Biol Chem 281, 26932-26942, 2006. http://dx.doi.org/10.1074/jbc.M601225200

Poy MN, Eliasson L, Krutzfeldt J, Kuwajima S, Ma X, Macdonald PE, Pfeffer S, Tuschl T, Rajewsky N, Rorsman P, Stoffel M. A pancreatic islet-specific microRNA regulates insulin secretion. Nature 432, 226-230, 2004. http://dx.doi.org/10.1038/nature03076

Poy MN, Hausser J, Trajkovski M, Braun M, Collins S, Rorsman P, Zavolan M, Stoffel M. miR-375 maintains normal pancreatic alpha- and beta-cell mass. Proc Natl Acad Sci USA 106, 5813-5818, 2009. http://dx.doi. org/10.1073/pnas.0810550106 
Raver-Shapira N, Marciano E, Meiri E, Spector Y, Rosenfeld N, Moskovits N, Bentwich Z, Oren M. Transcriptional activation of miR-34a contributes to p53-mediated apoptosis. Mol Cell 26, 731-734, 2007. http://dx.doi. org/10.1016/j.molcel.2007.05.017

Reinhart BJ, Slack FJ, Basson M, Pasquinelli AE, Bettinger JC, Rougvie AE, Horvitz HR, Ruvkun G. The 21-nucleotide let-7 RNA regulates developmental timing in Caenorhabditis elegans. Nature 403, 901-906, 2000. http:// dx.doi.org/10.1038/35002607

Riester A, Issler O, Spyroglou A, Rodrig SH, Chen A, Beuschlein F. ACTH-dependent regulation of microRNA as endogenous modulators of glucocorticoid receptor expression in the adrenal gland. Endocrinology 153, 212-222, 2012. http://dx.doi.org/10.1210/en.2011-1285

Robertson S, MacKenzie SM, Alvarez-Madrazo S, Diver LA, Lin J, Stewart PM, Fraser R, Connell JM, Davies E. MicroRNA-24 is a novel regulator of aldosterone and cortisol production in the human adrenal cortex. Hypertension 62, 572-578, 2013. http://dx.doi.org/10.1161/HYPERTENSIONAHA.113.01102

Rodriguez A, Griffiths-Jones S, Ashurst JL, Bradley A. Identification of mammalian microRNA host genes and transcription units. Genome Res 14, 1902-1910, 2004. http://dx.doi.org/10.1101/gr.2722704

Romero DG, Plonczynski MW, Carvajal CA, Gomez-Sanchez EP, Gomez-Sanchez CE. Microribonucleic acid-21 increases aldosterone secretion and proliferation in H295R human adrenocortical cells. Endocrinology 149, 2477-2483, 2008. http://dx.doi.org/10.1210/en.2007-1686

ShendeVR, GoldrickMM, RamaniS, Earnest DJ.Expression and Rhythmic Modulation ofCirculating MicroRNAs Targeting theClockGeneBmal1 in Mice.PLoSOne6,e22586,2011.http://dx.doi.org/10.1371/journal.pone.0022586

Shi R, Chiang VL. Facile means for quantifying microRNA expression by real-time PCR. Biotechniques 39, 519-525, 2005. http://dx.doi.org/10.2144/000112010

Schmittgen TD, Jiang J, Liu Q, Yang L. A high-throughput method to monitor the expression of microRNA precursors. Nucleic Acids Res 32, e43, 2004. http://dx.doi.org/10.1093/nar/gnh040

Schmittgen TD, Lee EJ, Jiang J, Sarkar A, Yang L, Elton TS, Chen C. Real-time of PCR quantification precursor and mature microRNA. Methods 44, 31-38, 2008. http://dx.doi.org/10.1016/j.ymeth.2007.09.006

Schwarz DS, Hutvagner G, Du T, Xu Z, Aronin N, Zamore PD. Asymmetry in the assembly of the RNAi enzyme complex. Cell 115, 199-208, 2003. http://dx.doi.org/10.1016/S0092-8674(03)00759-1

Suh N, Baehner L, Moltzahn F, Melton C, Shenoy A, Chen J, Blelloch R. MicroRNA function is globally suppressed in mouse oocytes and early embryos. Curr Biol 20, 271-277, 2010. http://dx.doi.org/10.1016/j.cub.2009.12.044

Tang R, Li L, Zhu D, Hou D, Cao T, Gu H, Zhang J, Chen J, Zhang CY, Zen K. Mouse miRNA-709 directly regulates miRNA-15a/16-1 biogenesis at the posttranscriptional level in the nucleus: evidence for a microRNA hierarchy system. Cell Res 3, 504-515, 2012. http://dx.doi.org/10.1038/cr.2011.137

Thomson JM, Newman M, Parker JS, Morin-Kensicki EM, Wright T, Hammond SM. Extensive post-transcriptional regulation of microRNAs and its implications for cancer. Genes Dev 20, 2202-2207, 2006. http://dx.doi. org/10.1101/gad.1444406

Timmermans S, Van Hauwermeiren F, Puimege L, Dejager L, Van Wonterghem E, Vanhooren V, Mestdagh P, Libert C, Vandenbroucke RE. Determining differentially expressed miRNAs and validating miRNA-target relationships using the SPRET/Ei mouse strain. Mamm Genome 26, 94-107, 2015. http://dx.doi.org/10.1007/ s00335-014-9550-y

Van Nieuwerburgh F, Soetaert S, Podshivalova K, Ay-Lin Wang E, Schaffer L, Deforce D, Salomon DR, Head SR, Ordoukhanian P. Quantitative bias in Illumina TruSeq and a novel post amplification barcoding strategy for multiplexed DNA and small RNA deep sequencing. PLoS One 6, e26969, 2011. http://dx.doi.org/10.1371/ journal.pone.0026969

van Rooij E. The art of microRNA research. Circ Res 108, 219-234, 2011. http://dx.doi.org/10.1161/CIRCRESAHA.110.227496

Vasudevan S. Functional validation of microRNA-target RNA interactions. Methods 58, 126-134, 2012. http://dx.doi. org/10.1016/j.ymeth.2012.08.002

Ventura A, Young AG, Winslow MM, Lintault L, Meissner A, Erkeland SJ, Newman J, Bronson RT, Crowley D, Stone JR, Jaenisch R, Sharp PA, Jacks T. Targeted deletion reveals essential and overlapping functions of the miR-17 through 92 family of miRNA clusters. Cell 132, 875-886, 2008. http://dx.doi.org/10.1016/j.cell.2008.02.019

Wang Y, Medvid R, Melton C, Jaenisch R, Blelloch R. DGCR8 is essential for microRNA biogenesis and silencing of embryonic stem cell self-renewal. Nat Genet 39, 380-385, 2007. http://dx.doi.org/10.1038/ng1969

Wang D, Zhang Z, O’Loughlin E, Lee T, Houel S, O’Carroll D, Tarakhovsky A, Ahn NG, Yi R. Quantitative functions of Argonaute proteins in mammalian development. Genes Dev 26, 693-704, 2012. http://dx.doi.org/10.1101/ gad.182758.111 
Wang L, Xu C. Role of microRNAs in mammalian spermatogenesis and testicular germ cell tumors. Reproduction 149, R127-137, 2015. http://dx.doi.org/10.1530/REP-14-0239

Wickramasinghe NS, Manavalan TT, Dougherty SM, Riggs KA, Li Y, Klinge CM. Estradiol downregulates miR-21 expression and increases miR-21 target gene expression in MCF-7 breast cancercells. Nucleic Acids Res 37, 2584-2595, 2009. http://dx.doi.org/10.1093/nar/gkp117

Wu Q, Song R, Ortogero N, Zheng H, Evanoff R, Small CL, Griswold MD, Namekawa SH, Royo H, Turner JM, Yan W. The RNase III enzyme DROSHA is essential for microRNA production and spermatogenesis. J Biol Chem 287, 25173-25190, 2012. http://dx.doi.org/10.1074/jbc.M112.362053

Wu S, Sun H, Zhang Q, Jiang Y, Fang T, Cui I, Yan G, Hu Y. MicroRNA-132 promotes estradiol synthesis in ovarian granulosa cells via translational repression of Nurr1. Reprod Biol Endocrinol 13, 94, 2015. http://dx.doi. org/10.1186/s12958-015-0095-Z

Xu S, Witmer PD, Lumayag S, Kovacs B, Valle D. MicroRNA (miRNA) transcriptome of mouse retina and identification of a sensory organ-specific miRNA cluster. J Biol Chem 282, 25053-25066, 2007. http://dx.doi. org/10.1074/jbc.M700501200

Yan Y, Salazar TE, Dominguez JM 2nd, Nguyen DV, Li Calzi S, Bhatwadekar AD, Qi X, Busik JV, Boulton ME, Grant MB. Dicer expression exhibits a tissue-specific diurnal pattern that is lost during aging and in diabetes. PLoS One 8, e80029, 2013. http://dx.doi.org/10.1371/journal.pone.0080029

Yang WJ, Yang D, Na S, Sandusky G, Zhang Q, Zhao G. Dicer is required for embryonic angiogenesis during mouse development. J Biol Chem 280, 9330-9335, 2004. http://dx.doi.org/10.1074/jbc.M413394200

Yang M, Lee JE, Padgett RW, Edery I. Circadian regulation of a limited set of conserved microRNAs in Drosophila. BMC Genomics 9, 83, 2008. http://dx.doi.org/10.1186/1471-2164-9-83

Yang Y, Chang S, Zhao Z, Hou NI, He K, Wang X, Gao L, Wang L, Cai D, Guo BO, Tong D, Song T, Huang C. MicroRNA-214 suppresses the proliferation of human hepatocellular carcinoma cells by targeting E2F3. Oncol Lett 10, 3779-3784, 2015. http://dx.doi.org/10.3892/ol.2015.3745

Yi R, Qin Y, Macara IG, Cullen BR. Exportin-5 mediates the nuclear export of pre-microRNAs and short hairpin RNAs. Genes Dev 17, 3011-3016, 2003. http://dx.doi.org/10.1101/gad.1158803

Yin M, Lu M, Yao G, Tian H, Lian J, Liu L, Liang M, Wang Y, Sun F. Transactivation of microRNA-383 by steroidogenic factor-1 promotes estradiol release from mouse ovariangranulosa cells by targeting RBMS1. Mol Endocrinol 26, 1129-1143, 2012. http://dx.doi.org/10.1210/me.2011-1341

Zhang X, Zeng Y. Regulation of mammalian microRNA expression. J Cardiovasc Transl Res 3, 197-203, 2010. http:// dx.doi.org/10.1007/s12265-010-9166-X

Zhang Z, Qin YW, Brewer G, Jing Q. MicroRNA degradation and turnover: regulating the regulators. Wiley Interdiscip Rev RNA 3, 593-600, 2012. http://dx.doi.org/10.1002/wrna.1114

Zhang N, Lin JK, Chen J, Liu XF, Liu JL, Luo HS, Li YQ, Cui S. MicroRNA 375 mediates the signaling pathway of corticotropin-releasing factor (CRF) regulating pro-opiomelanocortin (POMC) expression by targeting mitogen-activated protein kinase 8. J Biol Chem 288, 10361-10373, 2013. http://dx.doi.org/10.1074/jbc. M112.425504 